\title{
THE DESTRUCTION OF RED CELLS BY ANTIBODIES IN MAN. I. OBSERVATIONS ON THE SEQUESTRATION AND LYSIS OF RED CELLS ALTERED BY IMMUNE MECHANISMS ${ }^{1}$
}

\author{
By JAMES H. JANDL, A. RICHARDSON JONES, AND WILLIAM B. CASTLE

\begin{abstract}
(From the Thorndike Memorial Laboratory and Second and Fourth (Harvard) Medical
Services, Boston City Hospital, the Department of Medicine, Harvard Medical School, and the Blood Grouping Laboratory of Boston, Boston, Mass.)
\end{abstract}

(Submitted for publication May 9, 1957 ; accepted June 25, 1957)

Much of our present knowledge of the pathologic physiology of the acquired hemolytic anemias originated from observations of the fate of heterologous red cells in immunized animals and of the syndromes produced in animals by injections of heterologous anti-red cell sera (1-17). The frank hemolysins present in anti-red cell sera seemed to provide a complete explanation for the experimental findings, but it was early stressed by Muir and M'Nee (6) and by Banti (8) that the hemolytic action of hemolysin-containing sera was greater in extent and slower in evolution when injected into the intact animal than when added to red cells in vitro. It was also pointed out by Banti (8) and by others $(12,14)$ that anti-red cell sera produced spherocytosis of red cells in vivo but failed to do so in vitro. In humans it was proposed that spontaneous hemolysins may provoke the clinical picture of acquired hemolytic anemia $(5,9,10)$, particularly when associated with high titers of cold agglutinins $(18,19)$. However, clinical experience with acquired hemolytic anemia as well as with blood transfusion reactions and erythroblastosis fetalis has indicated that these hemolytic syndromes are generally not associated with hemolysins demonstrable in vitro $(20,21)$; and the injection into animals $(14,17,22)$ or into man (23-26) of antibodies which agglutinate but do not directly hemolyze red cells in vitro may reproduce the full picture of clinical hemolytic disease. Indeed, a number of investigators have observed the formation of intravascular red cell agglutinates in vivo after injection of heterologous or homologous immune serum $(4,14,15,24,27)$. In many patients suffering from hemolytic reactions, in almost all infants afflicted with erythro-

\footnotetext{
1 This investigation was supported in part by a grant from the Helen Hay Whitney Foundation, and by Research Grants RG3507(C3) and H1227 from the National Institutes of Health, Public Health Service.
}

blastosis fetalis, and in most patients with acquired hemolytic anemia, it is not even possible to demonstrate "complete" agglutinins. In these conditions the antibodies (actual or presumed) are agglutinins only in the sense that they "sensitize" red cells to the agglutinating effect in vitro of antiglobulin (Coombs) serum, of sufficient concentrations of plasma proteins or of certain other large anisometric anionic molecules (28-30). Although the hemolytic effect of hemolysins in vivo may be inferred from their manifest effects in vitro, the mechanism of the hemolytic action in vivo of agglutinating and of sensitizing antibodies has remained obscure. In the present study, use was made of the $\mathrm{Cr}^{\mathrm{st}}$ method for labelling small volumes of red cells for red cell survival studies $(31,32)$ and for determining the sites of red cell sequestration in living subjects (33). The subjects on whom observations were made included normal adults who had previously suffered accidental isoimmunization through transfusion or pregnancy. Some of these findings have been presented in preliminary form elsewhere (34-36).

\section{METHODS}

Techniques employing $\mathrm{Cr}^{51}$. $\mathrm{Cr}^{51}$ in the form of $\mathrm{Na}_{2} \mathrm{Cr}^{\mathrm{N1}} \mathrm{O}_{4}{ }^{2}$ was employed for red cell labelling (31) as adapted for studies of red cell survival by Ebaugh, Emerson, and Ross (32). Volumes of sodium chromate solution possessing an activity of 100 to 150 microcuries of $\mathrm{Cr}^{61}$ were added to 30 to $40 \mathrm{ml}$. of freshly-drawn blood and $12 \mathrm{ml}$. of ACD solution in sterile $100-\mathrm{ml}$. siliconized flasks. Following 45 minutes of gentle continuous agitation of the flasks at room temperature, their contents were centrifuged in sterile tubes and the supernatant solutions were removed. The packed cells were washed once in sterile isotonic saline, prior to their resuspension in saline to a final volume of about $30 \mathrm{ml}$. The suspensions were injected in a period of about one minute.

Samples of blood were drawn periodically from the

2 "Rachromate" of high specific activity, Abbott Laboratories, North Chicago, Illinois. 
subject in each experiment into saline-wetted syringes and then were divided into two parts. One part, which was received into a bottle containing dry "balanced" oxalate, was lysed by repeated freezing and thawing to provide samples for measuring whole blood radioactivity. The other part, received into one-tenth of its volume of 3 per cent sodium citrate solution, was centrifuged to provide plasma for determination of plasma radioactivity. In each case the plasma was re-centrifuged prior to sampling. The radioactivity of 3-ml. samples of whole blood, plasma, urine, and the $\mathrm{Cr}^{\mathrm{ar}}$ standards, was determined in a well-type scintillation counter.

The distribution of radioactivity over the hearts, livers and spleens of subjects receiving injections of $\mathrm{Cr}^{\text {sil }}$ was determined with a directional scintillation counter. The methods employed and the interpretation of the data obtained with these procedures are described elsewhere (33).

Techniques employing $F e^{s^{0}}$. Walsh, Thomas, Chow, Fluharty, and Finch (37) have observed that human reticulocytes can incorporate $\mathrm{Fe}^{\infty}$ into hemoglobin in vitro. Accordingly, blood samples were utilized from several patients with reticulocyte-rich blood for observations of $\mathrm{Fe}^{\infty}$-labelled reticulocyte survival in vivo. A complex between $\mathrm{Fe}^{\mathrm{s}}$ and human iron-binding protein was obtained by slowly adding dilute $\mathrm{Fe}^{\infty} \mathrm{Cl}_{3}$ s to the subject's sterile heparinized plasma in an amount calculated not to exceed the subject's plasma iron-binding capacity. One volume of such $\mathrm{Fe}^{\infty}$-labelled plasma was then incubated at $37^{\circ} \mathrm{C}$. with one volume of reticulocyte-rich red cells for from one to two hours in sterile siliconized flasks. Since separate studies indicated that from 0.5 to 1 microgram of $\mathrm{Fe}^{\infty}$ was taken up by each cubic centimeter of reticulocytes under these conditions, the volume of red cells used was selected to contain between 5 and $10 \mathrm{ml}$. of reticulocytes in order to provide a suitable amount of radioactivity. Because at the end of the incubation period most of the $\mathrm{Fe}^{\mathrm{s0}}$ still remained in the plasma, the labelled red cells were washed in sterile isotonic saline five times prior to their resuspension in saline at a final volume of $50 \mathrm{ml}$. They were then injected intravenously.* In these suspensions over 99 per cent of the radioactivity was in the red cells; of this, between 50 and 90 per cent, generally about 70 per cent, was incorporated into hemoglobin as determined by filter paper electrophoresis 5 and the remainder was present in the

3 Abbott Laboratories, North Chicago, Illinois.

4 In compliance with the definition of tracer doses of radioactive isotopes in adult man as being that quantity of radioactive material emitting radiation in an amount less than a total of 1 rep (38), the maximum dose of $\mathrm{Fe}^{\mathrm{\omega}}$ given should not exceed 0.2 microcuries per kilogram body weight. In the studies reported here from 4 to 6 microcuries of $\mathrm{Fe}^{\infty}$ were injected.

$\checkmark$ Since serum iron-binding protein and hemoglobin migrate together in the commonly used alkaline barbital buffer, it is advisable, for the separation of these proteins, to employ a buffer with a $\mathrm{pH}$ intermediate between the isoelectric points of the proteins. For this purpose a $\mathbf{p H}$ $6.4,0.1$ molar phosphate buffer was selected. red cell membrane. None of the radioactivity was elutable from the labelled red cells during incubation in fresh plasma for 24 hours at $37^{\circ} \mathrm{C}$. The techniques of determining and of presenting data on blood and body surface radioactivity subsequent to the injection of $\mathrm{Fe}^{\mathrm{\omega}}$ were similar to those employed with $\mathrm{Cr}^{\mathrm{kn}}$-labelled red cells (33).

Techniques involving antisera and red cell sensitisation. Human antisera were obtained from persons who had suffered primary isoimmunization against the $C$ or $D$ antigens of the $\mathrm{Rh}$ system as a result of transfusion or pregnancy. These donors had subsequently been hyperimmunized by small injections of incompatible red cells. Serum or plasma drawn from these donors was confirmed as sterile by appropriate bacterial culture methods.

The sensitization of normal red cells was carried out by incubating together for one hour at $37^{\circ} \mathrm{C}$. a mixture of one volume of packed type $D$ red cells and two volumes of an appropriate antiserum diluted with an equal amount of saline. After incubation the cells were washed twice prior to injection. Blood from cases of erythroblastosis fetalis ${ }^{6}$ was obtained in $30-\mathrm{ml}$. amounts via the umbilical vein prior to the first transfusion in exchange transfusions. In all experiments, the labelled, sensitized, washed red cell suspensions used were examined for hemoglobin and $\mathrm{Cr}^{\mathrm{B}}$ concentrations, for agglutination by Coombs serum and by polyvinylpyrrolidone (P.V.P.) (30) and for possible bacterial contamination.

Miscellaneous techniques. Plasma hemoglobin levels were determined by a photoelectric adaptation of the benzidine technique (39), using the same specimens em-

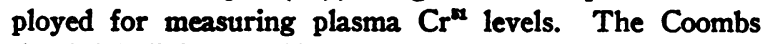
(antiglobulin) test (40) was performed using the tube technique with potent anti-human serum rabbit serum prepared as described by Emerson, Franklin, and Lowell (41). The technique of the "P.V.P. test" has been described elsewhere (30). Osmotic (42) and mechanical (43) fragilities of red cells were determined in several experiments. The $\mathrm{Cr}^{\text {activity }}$ of dog tissue specimens was determined after these tissues had been digested with 10 per cent $\mathrm{NaOH}$ and "homogenized" in a Waring blendor. The total protein concentration of heparinized dog plasma was measured by the microKjeldahl method (44) and the albumin concentration by the dye method (45). Serum bilirubin levels were determined by the photoelectric method $(46,47)$ and were recorded as the one-minute or prompt direct-reacting bilirubin ("direct bilirubin") and as total bilirubin.

Human subjects. The "normal" human subjects studied were generally elderly men with minor illnesses, in whom no diseases of the hematopoietic or reticulo-endothelial systems were believed to be present.

Animal subjects. Adult male mongrel dogs were anesthetized with Nembutali two hours prior to the injection of autogenous $\mathrm{Cr}^{\mathrm{m}}$-labelled red cells and remained unconscious until sacrificed. A few minutes prior to sacrifice of each animal $50 \mathrm{mg}$. of heparin was injected intravenously. Agglutination of canine red cells in vitro was produced by exposing the washed labelled red cells to

- We are indebted to Dr. Jane Desforges for assistance in procuring several of these specimens. 
trivalent chromium $\left(\mathrm{CrCl}_{8}\right)$, one of many multivalent cations which agglutinate the red cells of various species (48). "Sensitization" of canine red cells to agglutination by Coombs serum was achieved by incubating specimens of whole blood with a subagglutinating amount of trivalent chromium $\left(\mathrm{CrCl}_{8}\right)^{7}$ The extent of "sensitization" was determined with a specially prepared Coombs serum (anti-dog serum rabbit serum) and with P.V.P. "Spleen

${ }^{7}$ The manner in which certain multivalent cations such as $\mathrm{Cr}^{+++}$"sensitize" red cells to the agglutinating action of Coombs serum is presented elsewhere (48). These metals are entirely inactive in this respect when in anionic complexes such as chromate. blood" was obtained by deeply incising the splenic parenchyma after clamping the splenic pedicle and rapidly excising the organ. The effluent blood was allowed to flow directly into test tubes containing heparin.

\section{RESULTS}

\section{Sequestration of red cells altered by antibodies}

Agglutinating antibodies. Several observations were made on the fate of ABO-incompatible normal red cells in subjects in whom normal agglutinin titers were present and in whom low con-

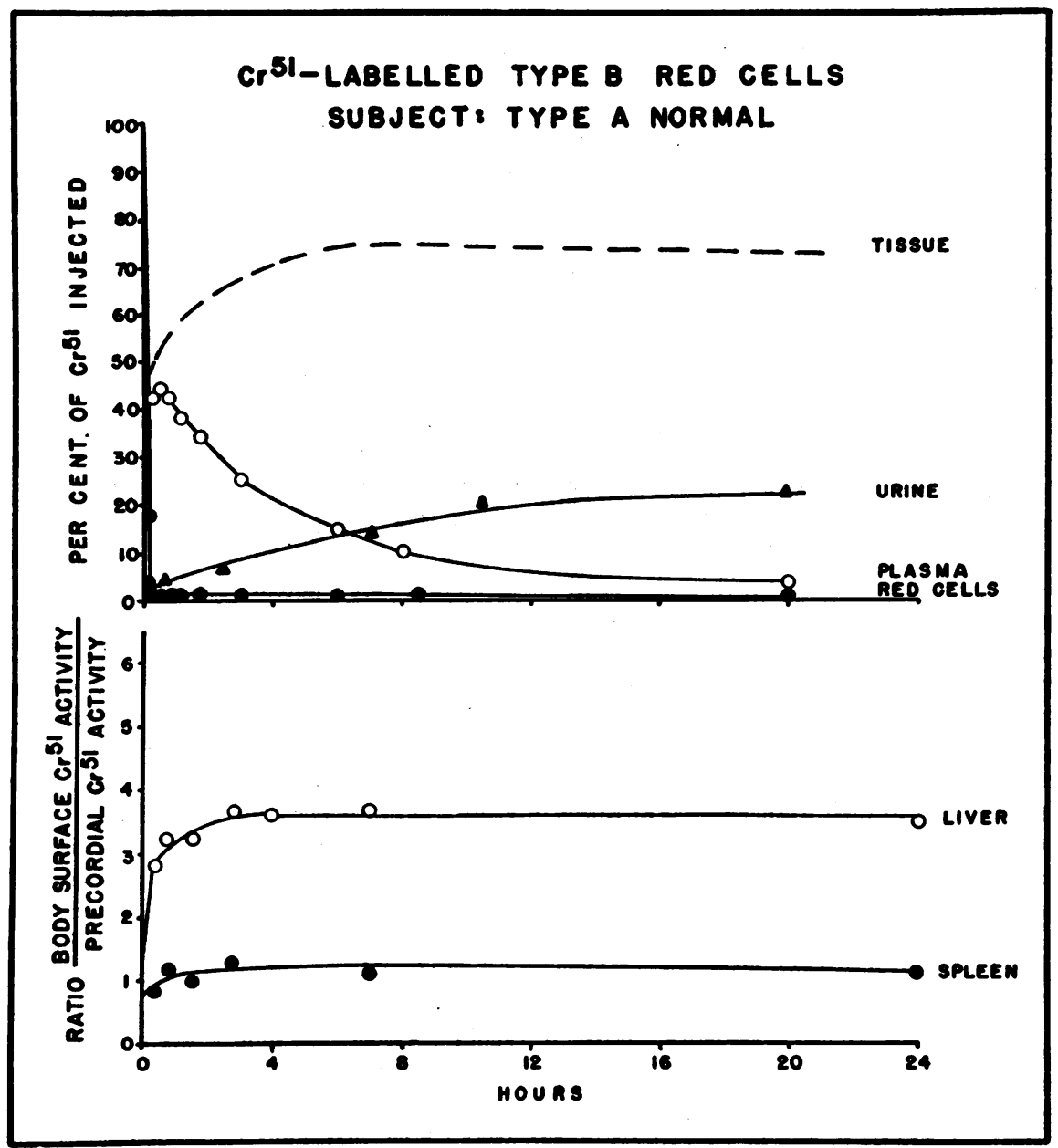

Fig. 1. Destruction of Type B Red Cells in a normal Type A Recipient Whose Serum Contained Isoagglutinins and Weak Isohemolysins

Virtually all of the red cell $\mathrm{Cr}^{\text {ot }}$ activity disappeared from the recipient's circulation within two minutes after injection of these incompatible red cells, with the prompt appearance of high levels of $\mathrm{Cr}^{\text {si }}$ (and of hemoglobin) in the plasma. Approximately 25 per cent of the injected $\mathrm{Cr}^{\mathrm{m}}$ appeared in the urine within 24 hours of the injection. That radioactivity not present in red cells, plasma, or urine was presumably in "tissue." The "organ" distribution of tissue $\mathrm{Cr}^{51}$ is depicted in the lower portion of this figure, where the prompt and comparatively high radioactivity of the liver is apparent. 


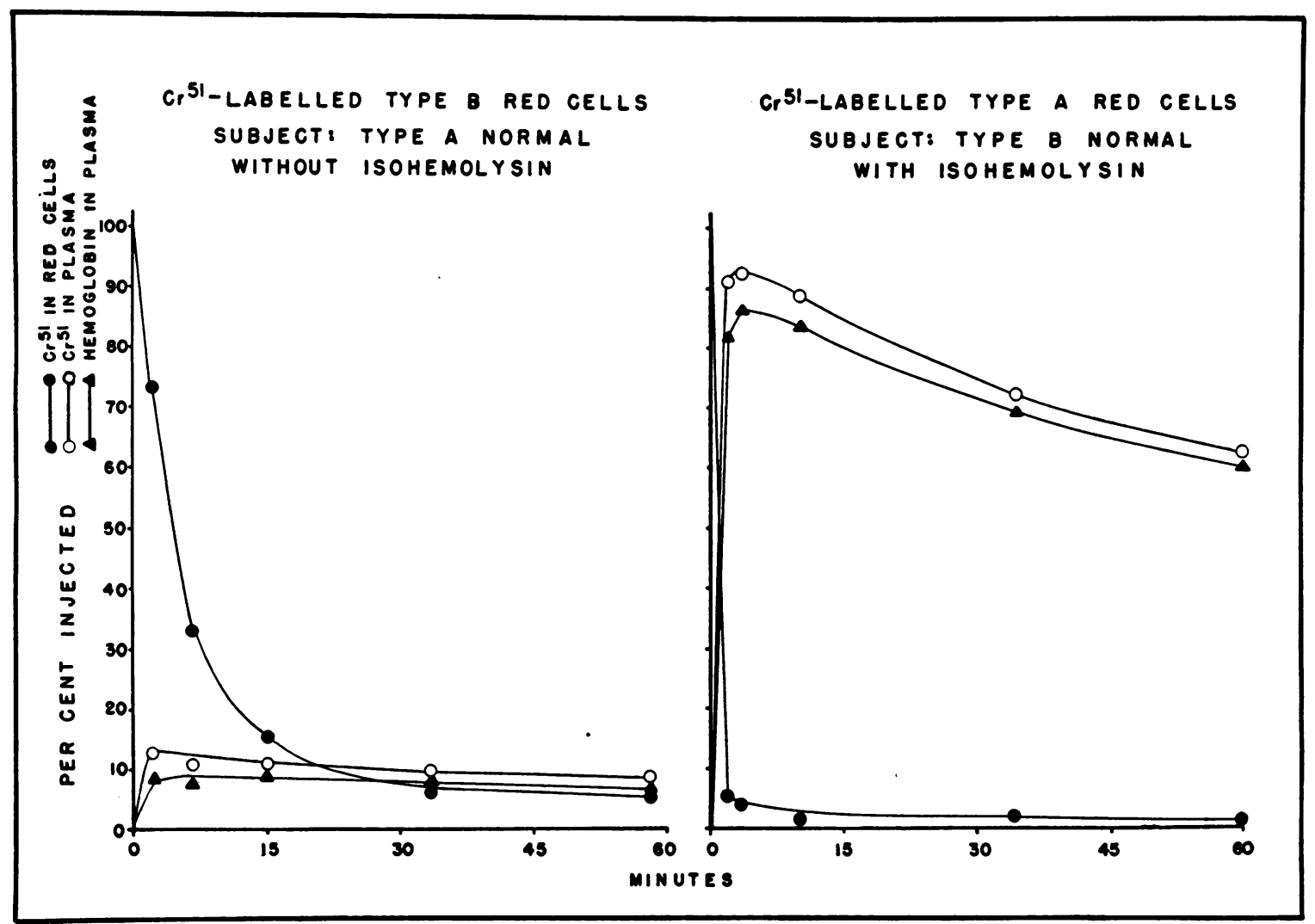

Fig. 2. Comparison of the Pattern of Destruction of Normal Red Ceils by Isoagglutinins and by ISOHEMOLYSINS

a. Type B red cells (left above) injected into a normal type A subject with a 1:64 titer of anti-B agglutinin, but without anti-B hemolysin demonstrable in vitro, were removed rapidly (half-disappearance time: 4 minutes), with the appearance of immediate but relatively low levels of $\mathrm{Cr}^{51}$ and of hemoglobin in the plasma. There was a heavy $\mathrm{Cr}^{51}$ accumulation by the liver. After 60 minutes the relative radioactivity values were: liver/precordium, 7.13; spleen/precordium, 1.86. After 18 hours when the plasma radioactivity had declined to low levels the liver/precordium ratio was unchanged.

b. The injection of type A red cells (right above) into a normal type B subject with a 1:256 titer of anti-B agglutinin, whose undiluted fresh serum caused 2 plus hemolysis of type B red cells in vitro, produced immediate disappearance of 90 per cent of the injected $\mathrm{Cr}^{51}$-labelled red cells from the blood stream, and comparatively high levels of $\mathrm{Cr}^{51}$ and of hemoglobin in the plasma. In this subject hepatic radioactivity was less striking and slower to appear. After 60 minutes the relative radioactivity values were: liver/precordium, 1.72; spleen/precordium, 1.02. After 18 hours, when plasma radioactivity had declined to low levels, the liver/precordium ratio was 2.94 .

centrations of isohemolysins were demonstrable in vitro. ${ }^{8}$ A representative observation is por-

8 In evaluating the activity in vitro of isohemolysins or other antibodies it is important to employ the same ratio of serum to cells which is to be studied in vivo. In normal subjects complete hemolysis often occurred only when this ratio was greater than 500:1 (the ratios achieved in vivo averaged about $200: 1$ ), whereas none occurred at ratios of less than $100: 1$ or $200: 1$. Presumably a critical concentration of hemolysin must be absorbed on each cell, and a zone of "antigen excess" may obscire results derived from conventional in vitro serum-cell ratios of $100: 1$ or less. trayed in Figure 1. The $\mathrm{Cr}^{51}$-labelled red cells are seen largely to disappear from the circulation within two minutes of the injection, in association with the abrupt appearance of high levels of radioactivity over the patient's liver, but not over the spleen, thorax, or lumbosacral areas. This appearance of high hepatic $\mathrm{Cr}^{51}$ levels occurred considerably faster than when $\mathrm{Cr}^{51}$-labelled hemoglobin was injected intravenously (33). Immediately after injection of the labelled ABO-incompatible cells, both $\mathrm{Cr}^{51}$ and hemoglobin appeared in the patient's plasma, reached maximum values 


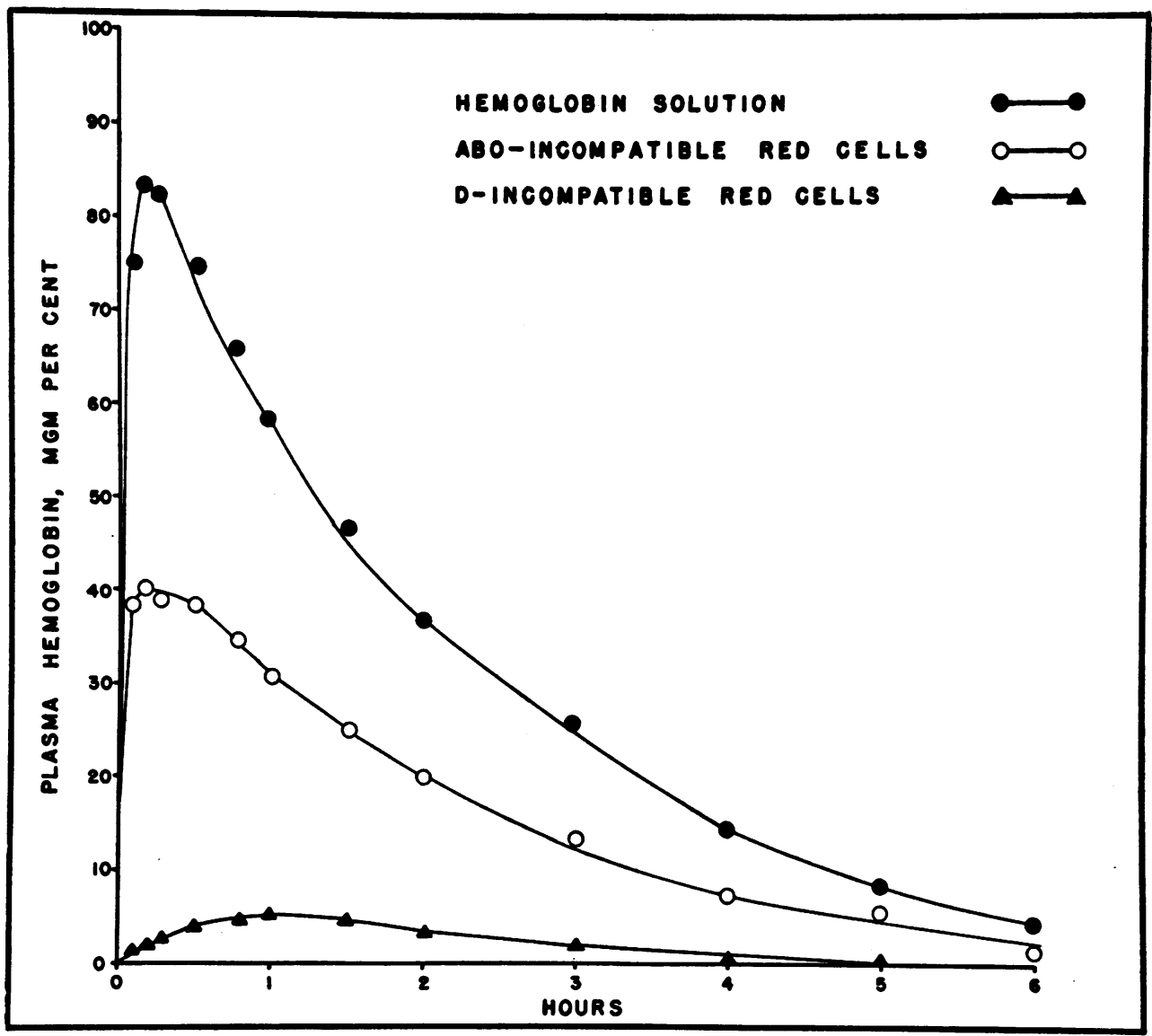

Fig. 3. Plasma Hemoglobin Levels in Normal Subjects following the Rapid Intravenous Injection of Various Preparations Containing Approximately 3 Gm. of HEMOGLOBIN

The points on each curve represent the average of data obtained from several subjects. The observed plasma hemoglobin values were corrected for pre-injection levels. Injection of $2.8 \mathrm{Gm}$. of hemoglobin in solution into each of three subjects produced no hemoglobinuria or hemosiderinuria; following a mixing period of 15 minutes, the plasma hemoglobin levels diminished exponentially with a half-disappearance time of about 100 minutes. Injection of ABO-incompatible red cells containing a similar amount of hemoglobin into seven normal subjects, two of whom had no demonstrable hemolysins against the injected red cells, caused less hemoglobinemia. Following a longer mixing period of about 35 minutes, the plasma hemoglobin levels also declined exponentially, with a half-disappearance time of about 90 minutes. Injection of comparable amounts of type $\mathrm{D}$ red cells into three subjects previously immunized against the $\mathrm{D}$ factor and possessing high titers of incomplete anti-D antibodies produced much smaller and more gradual rises in plasma hemoglobin levels (see Figure 12 for the results in individual patients).

of about 40 per cent of the injected $\mathrm{Cr}^{51}$ and hemoglobin within five or six minutes, and gradually diminished thereafter over a period of several hours. A fairly prominent excretion of $\mathrm{Cr}^{51}$ was found in the urine but hemoglobinuria was not detected. Observations were made on the fate of ABO-incompatible red cells injected into two subjects having normal isoagglutinin titers but in whom no isohemolysins were demonstrable in vitro at any serum-to-cell ratio despite the addition of fresh complement. In these subjects the $\mathrm{Cr}^{51}$ and hemoglobin contents of the circulating plasma rose immediately to approximately 10 per cent of the amounts injected and did not thereafter exceed this comparatively low level (Figure 2a). As compared to the first group of subjects, the labelled 
red cells disappeared somewhat more slowly (halfsurvival time of four minutes and five minutes) and this was accompanied by marked and rapid accumulations of radioactivity in the livers of these subjects. Again, radioactivity over the spleen was relatively low, and there was no evidence of $\mathrm{Cr}^{51}$ accumulation in the lungs or lumbosacral area. Finally, in studies of subjects in whom high concentrations of isohemolysins were demonstrable, hemoglobinemia following the injection of incompatible red cells was pronounced, was abrupt in onset, and reached maximum levels within less than 60 seconds (Figure 2b). In each of two observations in such subjects over 90 per cent of the hemoglobin contained in the injected red cells could be accounted for in the circulating plasma. On the other hand, the hepatic accumulation of $\mathrm{Cr}^{51}$ was slower and much less striking.

In Figure 3 are compared the average plasma hemoglobin levels resulting from the injection of comparable amounts of hemoglobin in the form of hemoglobin solution in three normal subjects and in the form of ABO-incompatible red cells in seven subjects including those with and without demonstrable hemolysins. These two curves can be seen to differ in that only a portion of the hemoglobin derived from $\mathrm{ABO}$-incompatible red cells was released into the circulation (average: 42 per cent) and that there was a more prolonged hemoglobin "mixing" period after the injection of incompatible red cells than was the case when hemoglobin solution was directly injected.

Observations in human subjects of the rate of removal of red cells agglutinated in vitro by $\mathrm{ABO}$ incompatible serum prior to their injection were largely frustrated because antibodies on weakly- agglutinated cells tended to wash off during their preparation, and because strongly agglutinated cells were felt to constitute an embolic hazard. However, such studies were carried out on two normal type B subjects whose red cells were labelled with $\mathrm{Cr}^{51}$, washed in saline, and then moderately ("2 plus") agglutinated by exposure to anti-B serum. In the first of these studies 26 per cent of the injected red cells were almost immediately removed from the blood stream, with the appearance within 25 minutes of 6 per cent of the injected $\mathrm{Cr}^{51}$ in the recipient's plasma. The radioactivity of the liver at this time was 2.25 times that of the precordium, while the splenic radioactivity remained low. During the next two hours circulating red cell radioactivity increased to about 93 per cent of that injected and then slowly declined in a normal fashion thereafter. With the increase in the $\mathrm{Cr}^{51}$ activity of the circulating red cells, the hepatic radioactivity declined to 1.50 that of the precordium. The injection into a second normal type B subject of autogenous red cells moderately ("2 plus") agglutinated in vitro with serum containing anti-B led to no appreciable sequestration or destruction of these cells.

The fate in the dog of autogenous red cells, moderately-heavily ("3 plus") agglutinated by $\mathrm{CrCl}_{3}$ is presented in Table I. Here is depicted a marked retention of such red cells by the animal's lungs, with some uptake by the liver, and very little by the spleen.

Non-agglutinating ("incomplete") antibodies. Four subjects with high titers of incomplete anti-D antibody were injected with $\mathrm{Cr}^{51}$-labelled type $\mathrm{D}$ red cells. Type D red cells exposed to the sera of these subjects were sensitized to the antiglobu-

TABLE I

Organ distribution in two dogs of $\mathrm{Cr}^{\mathrm{b1}}$ derived from autogenous red cells previously labelled with $\mathrm{Na}_{2} \mathrm{Cr}^{\mathrm{B1}} \mathrm{O}_{4}$ and exposed to a multivalent metallic cation

\begin{tabular}{|c|c|c|c|c|c|c|c|c|c|}
\hline \multirow[b]{3}{*}{ Dog } & \multicolumn{2}{|c|}{ Red cell suspension } & \multirow[b]{3}{*}{ Method of preparation } & & & & & & \\
\hline & Agglutina- & & & \multicolumn{6}{|c|}{ Distribution of $\mathrm{Cr}^{k 2} 2$ hours after injection, \% } \\
\hline & & test & & Blood & Liver & Spleen & Lung & Kidney & Total \\
\hline S-2 & $3+$ & $0^{*}$ & Red cells in saline & 2.6 & 8.2 & 0.3 & 60.2 & 0.1 & 71.4 \\
\hline$S-4$ & $\mathbf{0}$ & $2+$ & $\begin{array}{c}\text { Red cells in serum } \\
\stackrel{+}{\mathrm{CrCl}_{2}}\end{array}$ & 62.9 & 7.8 & 25.9 & 0.3 & 0.1 & 97.0 \\
\hline
\end{tabular}

\footnotetext{
* That is, the intensity of agglutination was not augmented by an antiserum developed against dog serum in rabbits.
} 


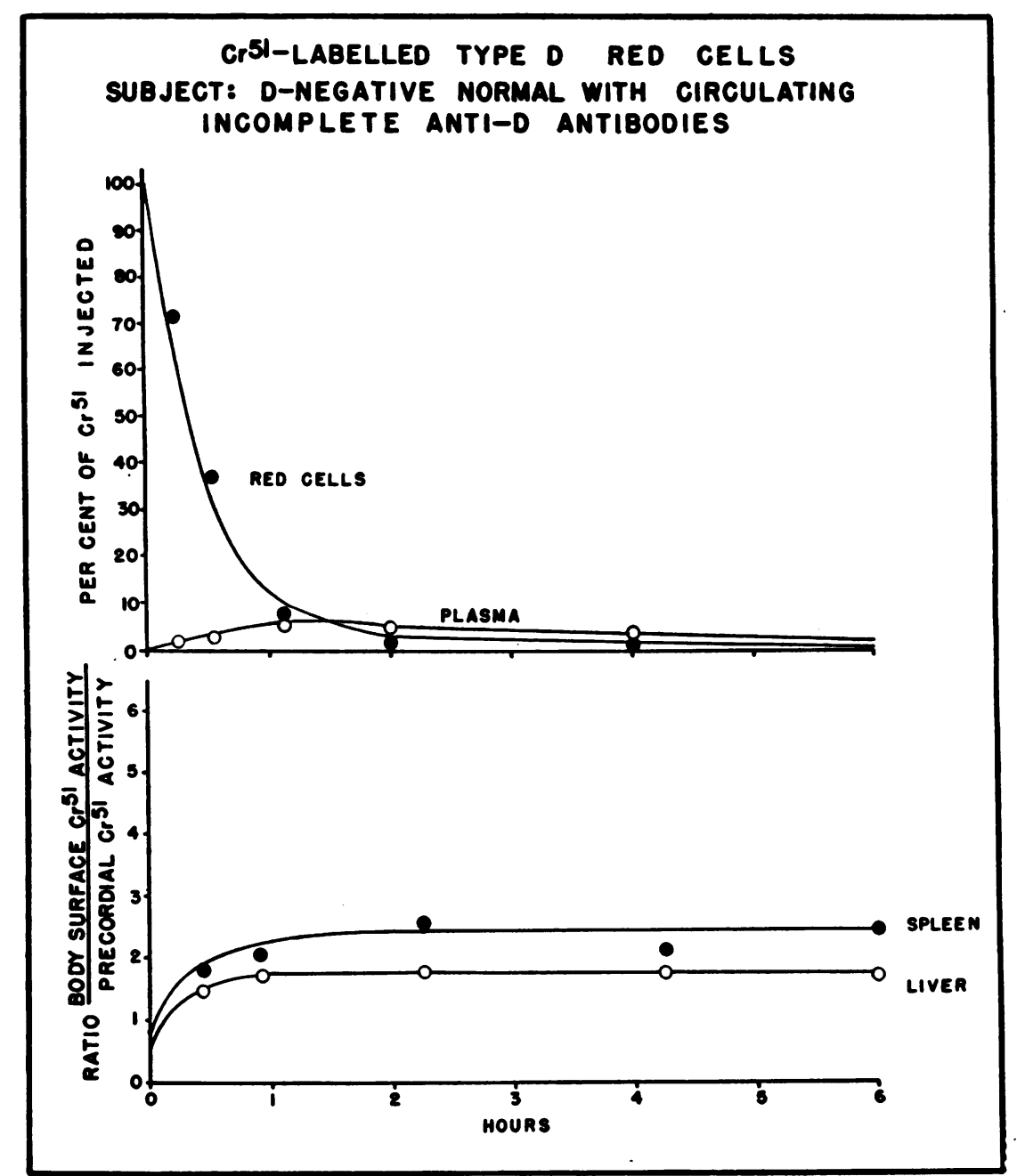

Fig. 4. Destruction of $C_{R}{ }^{\text {m}}$-Labelled Type D Red Cells in an Otherwise Normal D-Negative Subject Whose Serum Contained Incomplete Anti-D ANTIBOdIES

Following intravenous injection, half the red cell $\mathrm{Cr}^{\text {or }}$ activity disappeared from the patient's peripheral blood in 21 minutes, while plasma $\mathrm{Cr}^{\mathrm{os}}$ levels climbed to a maximum level of only 4.5 per cent of the injected dose about one hour after injection. A moderate accumulation of $\mathrm{Cr}^{\mathrm{s1}}$ in the subject's spleen, and a slightly smaller accumulation by the liver, occurred simultaneously with the disappearance of red cell $\mathrm{Cr}^{51}$.

lin reaction but were not agglutinated by resuspension in undehydrated native plasma. A representative study is portrayed in Figure 4, in which is seen the rapid removal of $\mathrm{Cr}^{51}$-labelled red cells from the circulation. The half-survival time of type $\mathrm{D}$ red cells in these hyperimmunized subjects ranged from 8 to 24 minutes, and averaged $14 \mathrm{~min}$ utes. In these studies an associated moderate uptake of $\mathrm{Cr}^{51}$ by the spleen and, to a lesser extent, by the liver was observed. Little or no $\mathrm{Cr}^{51}$ or hemoglobin appeared in the plasma when the in- jected red cells contained about $1 \mathrm{Gm}$. of hemoglobin, and both levels were low even when the hemoglobin content exceeded $6 \mathrm{Gm}^{\circ}$ and when the quantity of red cells destroyed within the first

${ }^{9}$ The injection of approximately $10 \mathrm{ml}$. of type $\mathrm{D}$ red cells into these subjects uniformly produced moderate to severe febrile reactions analogous to those produced by the injection of bacterial pyrogens. This also occurred when similar amounts of previously-sensitized red cells were given to normal subjects. The mechanisms of this reaction and of the associated leukopenia are now under study (49). 
10 minutes exceeded that of the $\mathrm{ABO}$ incompatibility studies described above. When these four subjects received injections of type $D$ red cells containing $3.3 \pm 0.5 \mathrm{Gm}$. of hemoglobin, the maximum levels of $\mathrm{Cr}^{51}$ and of hemoglobin in the plasma were attained about one hour after injection, at which time only about 5 per cent of the injected hemoglobin was present in the circulating plasma.

When the recipient's serum contained agglutinating as well as incomplete anti-C antibodies (Figure 5), the sequence of events was quite simi- lar to that of recipients with only incomplete antibodies (Figure 4), except that red cell sequestration was somewhat more rapid and hepatic radioactivity was more pronounced. Again, plasma hemoglobin and $\mathrm{Cr}^{51}$ levels increased slowly to reach maximum levels about one hour after the injection.

Additional studies were made on the destruction of $\mathrm{Cr}^{51}$-labelled D-positive normal red cells which had been sensitized in vitro with incomplete anti-D antibodies prior to their reinjection into the donor or into an ABO-compatible normal subject.

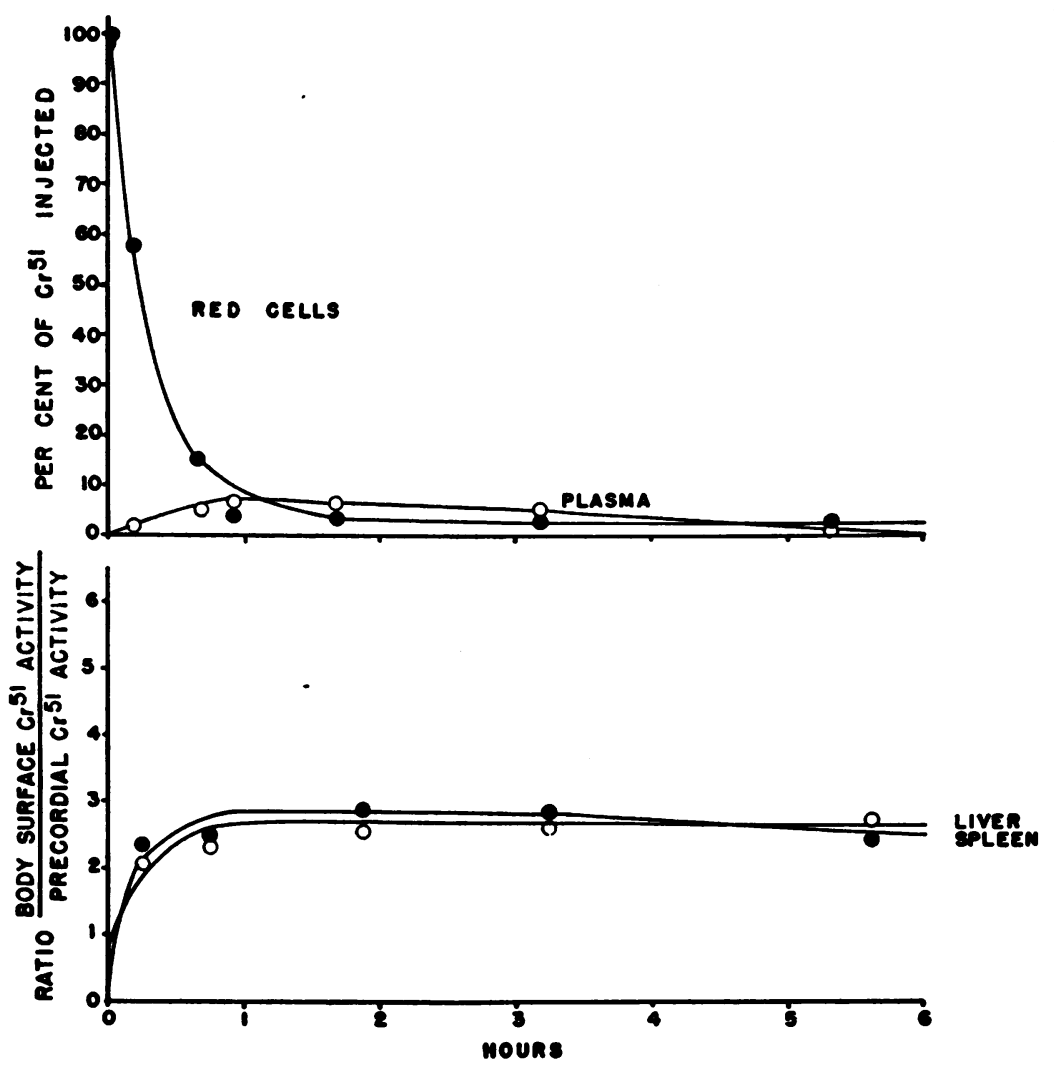

Fig. 5. Destruction of Type C Red Cells in an Otherwise Normal C-Negative Subject Whose Serum Contained Both Complete and Incomplete Anti-C Antibodies

Following their intravenous injection half of these red cells were removed from the blood stream within eight or nine minutes, with the plasma $\mathrm{Cr}^{\text {sil }}$ reaching a maximum value of only 6 per cent of the injected dose about one hour later. The liver and spleen were about equally active in sequestering these red cells. 


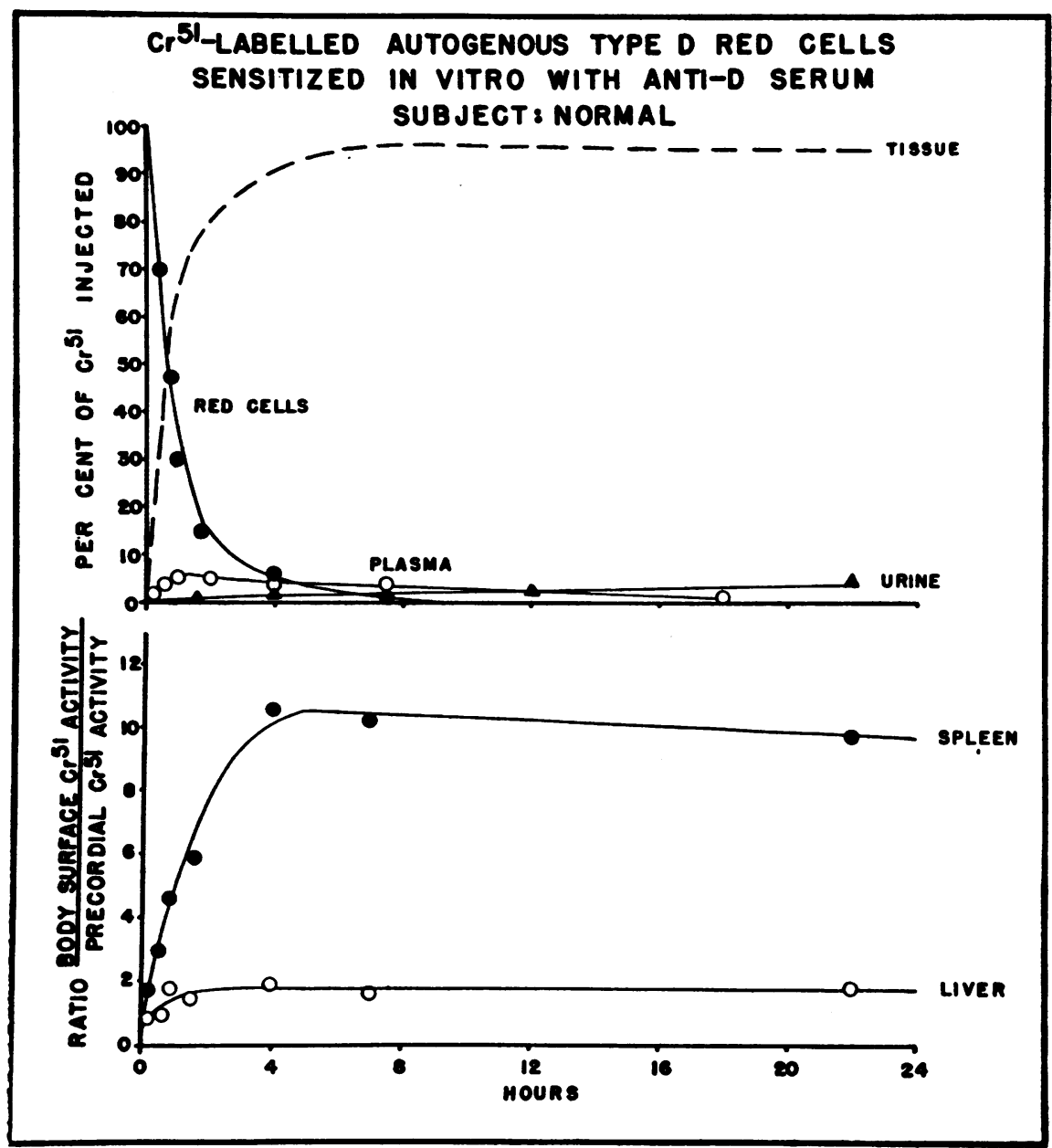

Fig. 6. Destruction in a Type D Normal Subject of Autogenous Red Cells Previously Sensitized In Vitro With Incomplete Anti-D Antibody

These red cells were strongly agglutinated by Coombs serum and by P.V.P. but showed no agglutination when suspended in normal serum. Their osmotic and mechanical fragilities were normal. Following their intravenous injection, there was a rapid exponential decline in red cell $\mathrm{Cr}^{51}$ activity, indicating a half-survival time of 30 minutes, with very little $\mathrm{Cr}^{51}$ (or hemoglobin) appearing in the plasma, and then only after a delay. Very little $\mathrm{Cr}^{51}$ appeared in the urine. Reflecting the disappearance of red cell $\mathrm{Cr}^{51}$, an inversely proportional build-up of radioactivity appeared in the spleen area. Little, if any, accumulation of $\mathrm{Cr}^{51}$ occurred in the subject's liver. In similar studies of six other normal subjects, the ratio of spleen to precordial $\mathrm{Cr}^{51}$ activity three to four hours after injection ranged from 4 to 14 . Most of these values exceed those which follow the injection of $\mathrm{Cr}^{51}$-labelled type $\mathrm{D}$ red cells into immunized D-negative subjects. (See Figure 4.)

When the successive procedures of $\mathrm{Cr}^{51}$-labelling, exposure to anti-serum, and saline washing were performed with D-negative red cells their subsequent survival in vivo was not affected. When, however, D-positive red cells were incubated with potent incomplete anti-serum, half of the injected sensitized cells were removed from the subjects' circulation in from 18 to 40 minutes (average, 26 minutes in seven subjects). A representative study is depicted in Figure 6, revealing the relatively rapid disappearance of labelled red cells associated with only slight increases of $\mathrm{Cr}^{51}$ and of hemoglobin in the plasma. Very little $\mathrm{Cr}^{51}$ appeared in the urine. During the first 15 or 20 minutes after the injection of the sensitized but originally unagglutinated red cells, small numbers of 
red cell agglutinates and chains were frequently visible in the recipient's peripheral blood. These could be most readily visualized by diluting the blood 200-fold in saline and examining the freelymoving cell suspension microscopically under a cover-slip with the "high dry" lens. Characteristic of, and concomitant with, the red cell destruction was a heavy build-up of $\mathrm{Cr}^{51}$ by the spleen, with little, if any, evidence of $\mathrm{Cr}^{51}$ accumulation by the liver. In three $\mathrm{ABO}-$ compatible, unimmunized D-negative subjects, D-positive red cells previously sensitized with potent anti-D serum were similarly sequestered in the spleen. With very potent sera (in terms of the P.V.P. test) the red cell disappearance rate was exponential. Less potent sera produced slower, diminishing rates of red cell destruction, in which various proportions of the sensitized red cells survived normally after an initial phase of rapid sequestration. That the red cell survival pattern was characteristic of the serum employed is evident in Figure 7 , where repeated study of the survival of $\mathrm{Cr}^{51}$-labelled cells sensitized in vitro provided reproducible results when the same serum and subject were used. As seen in Figure 7, this attempt at desensitization by repeated infusions of anti-D sensitized red cells did not alter the rate at which these cells were subsequently destroyed. These experiments with a homologous antibody failed to demonstrate the development of a protective "anti-antibody" mecha-

GSI-LABELLLD AUTOGENOUS TYPE D RED CELLS SENSITIZED IN VITRO WITH ANTI-D SERUM

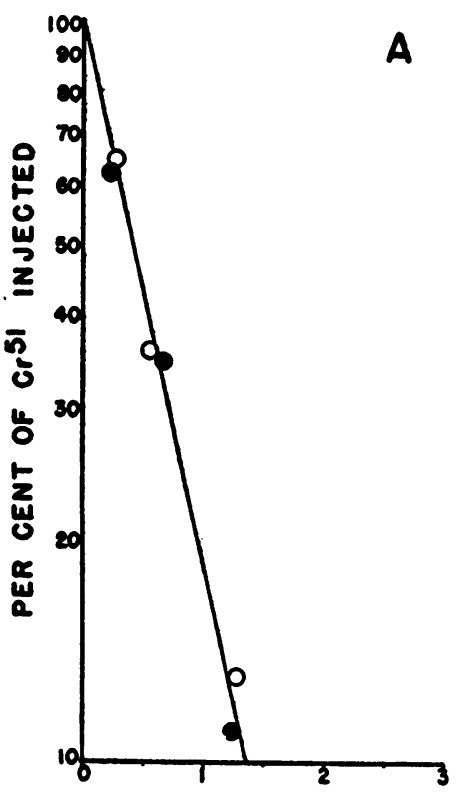
SUBJECTS: NORMAL

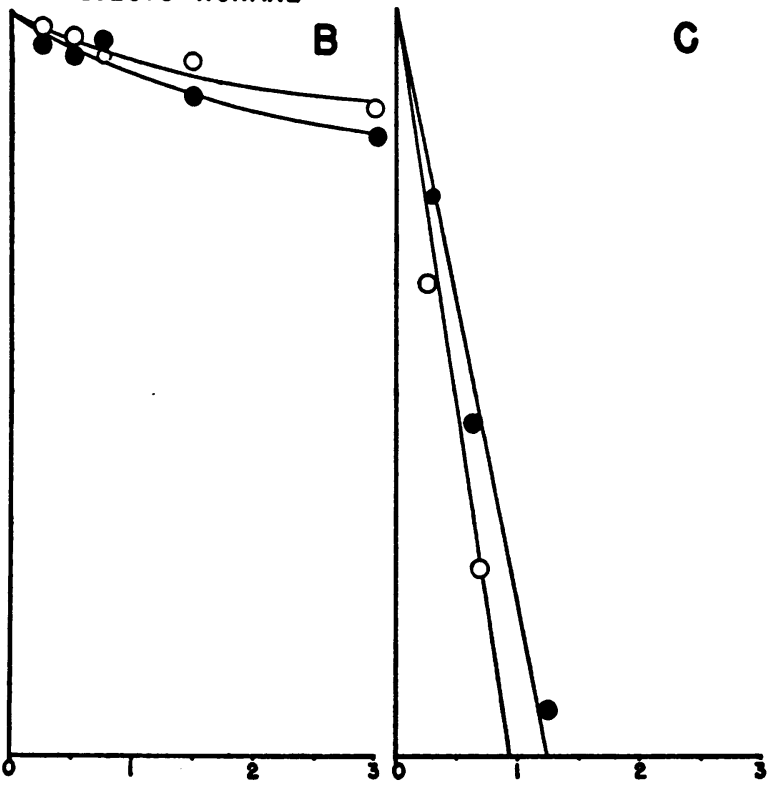

HOURS

Fig. 7. Negative Effect Upon Their Subsequent Rate of Destruction of Repeated Injections into Normal Type D Subjects of Autogenous Red Cells Previously SensiTIZED In $V$ itro With INCOMPLETE ANTI-D SERuM

Samples of red cells of each of three subjects were sensitized in vitro with two volumes of the same antiserum and injected intravenously on five occasions over the course of three weeks. The red cells were labelled with $\mathrm{Cr}^{\mathrm{s}}$ on the first (solid circles) and last (empty circles) occasions. The red cells of Subject $A$ and of Subject $C$ were sensitized with sera that produced strong agglutination of the cells in the "P.V.P. test." Their initial half-survival times were 27 and 20 minutes, respectively, and repeated injections of the sensitized red cells had no effect upon the subsequent survival of the sensitized autogenous cells. The serum employed in sensitizing the red cells of Subject B produced an equally intense Coombs reaction, but agglutinates of the sensitized cells that formed in the presence of P.V.P. slowly dissociated in saline. In vivo a relatively small portion of these cells was destroyed and splenic radioactivity rose slightly initially but not thereafter. Again repeated injections of the sensitized cells did not discernably affect their subsequent survival. 


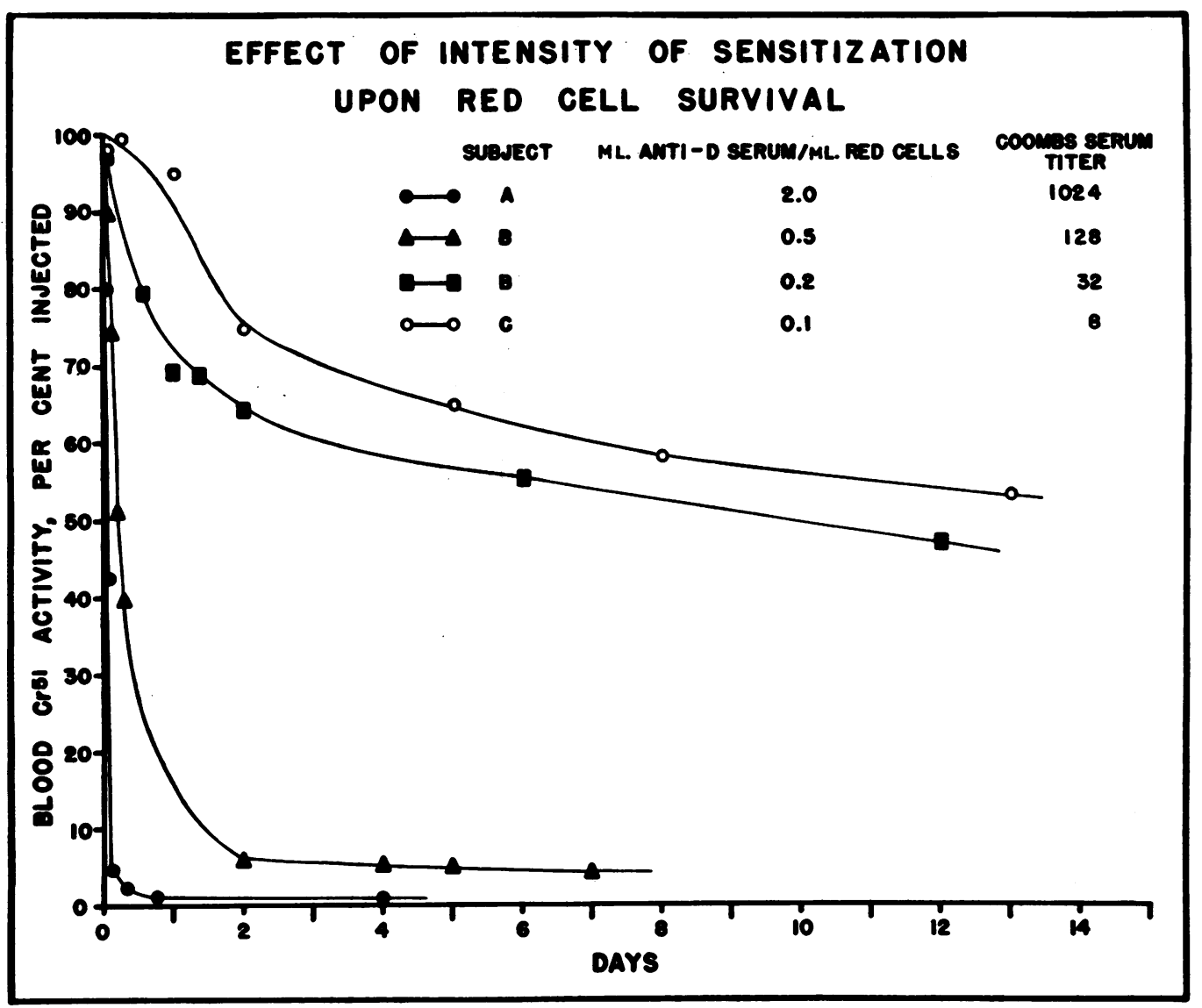

Fig. 8. Survival in Three Normal Type D Subjects of $C_{R}{ }^{51}$-Labelled Autogenous Red Cells After Exposure In Vitro to Various Amounts of the Same Anti-D Serum

The greater the quantity of serum employed per $\mathrm{ml}$. of red cells the higher the Coombs serum titer of the sensitized red cells in vitro and the greater the rate and extent of the subsequent destruction of these cells after injection into the subject.

nism analogous to that produced in animals against heterologous anti-red cell serum, as reported by Samaille and Jones (16). From Figure 8, it appears that the rate and extent of destruction of the sensitized labelled cells in the recipient were proportional to the volume of anti-D serum relative to that of the red cells employed in the sensitization procedure.

Four studies were made of the destruction of $\mathrm{Cr}^{51}$-labelled red cells from the cord blood of erythroblastotic infants after injection into ABOcompatible normal adult subjects. Figure 9 presents observations on the fate of such red cells from one of the two infants with severe erythroblastosis fetalis. In each observation there was rapid removal of the injected cells with evident splenic sequestration and only slight hemoglobi- nemia. In each instance, however, 25 to 30 per cent of the red cells survived normally. The pattern of destruction of red cells from milder cases of erythroblastosis fetalis resembled that of the weakly sensitized D-positive red cells shown in Figure 8. There was excellent agreement between the extent of destruction of erythroblastosis fetalis red cells transfused into adult recipients, the permanence on resuspension in saline of the red cell agglutinates produced by P.V.P., and the clinical severity of the hemolytic disease. On the other hand, the titer and intensity of the direct Coombs test did not show such a correlation.

The survival in a splenectomized subject of normal human red cells sensitized with incomplete anti-D serum was studied, employing in the sensitization procedure a serum known to cause seques- 
tration of half of such sensitized cells by the spleen of a normal subject within 30 minutes. In the splenectomized subject the half-survival of these cells was over four and one-half hours, and their disappearance from the blood stream was attended by a pronounced uptake of $\mathrm{Cr}^{51}$ by the patient's liver (Figure 10).

In order to determine the effect in vivo of hyperglobulinemia upon the survival of sensitized red cells, a D-positive subject with multiple myeloma and very high serum globulin levels (over $12 \mathrm{Gm}$. per cent) was reinjected with her own red cells which had been labelled with $\mathrm{Cr}^{51}$ and sensitized with incomplete anti-D serum. Whereas in normal subjects the half-survival of red cells treated with this serum was about 30 minutes, in this patient the half-survival time was about five minutes and almost 90 per cent of the sensitized red cells

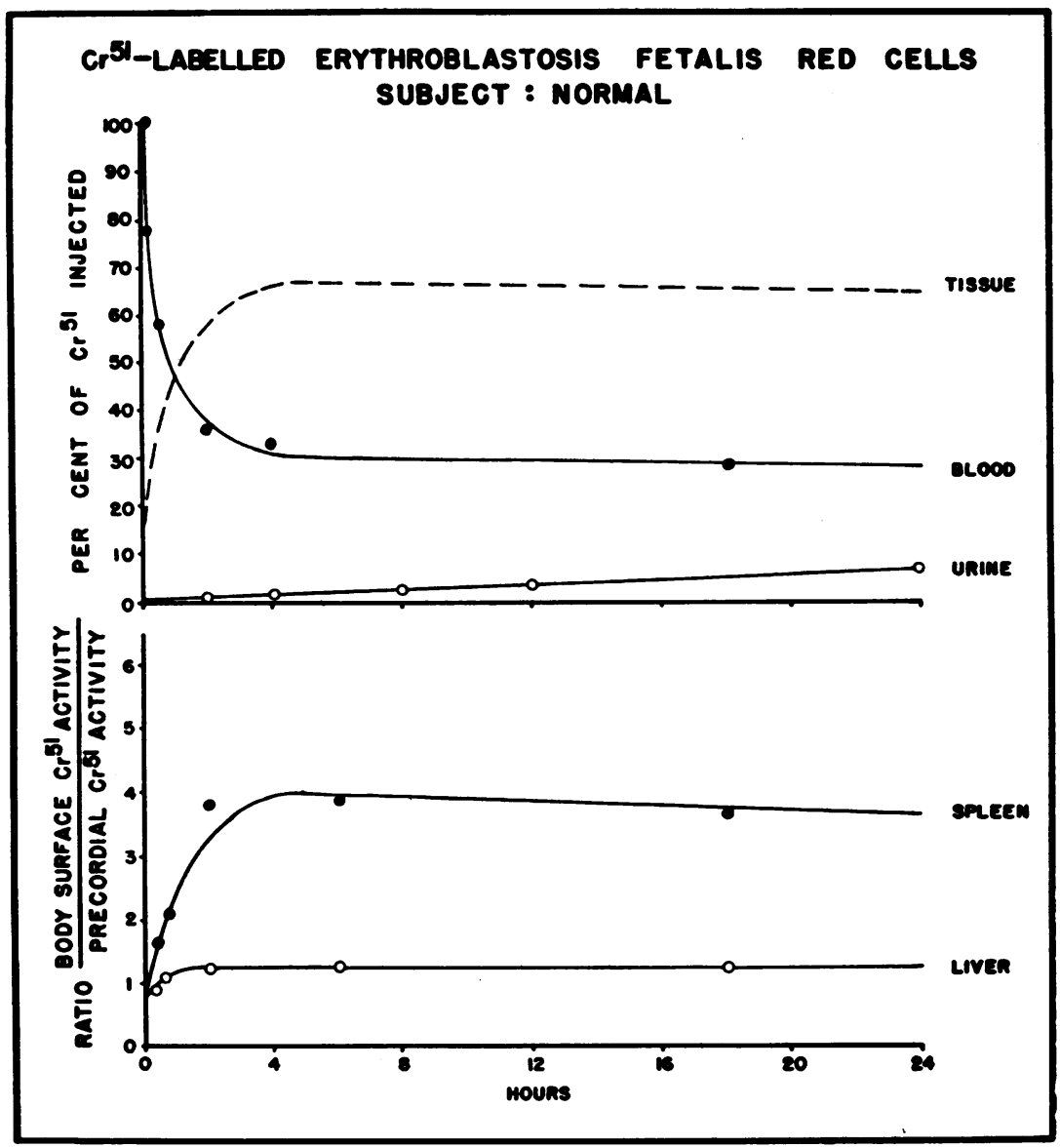

Fig. 9. Survival in a Normal Compatible Adult of Red Ceils From the Cord Blood of an Infant With Erythroblastosis Fetalis

The red cells employed were removed prior to the first of three exchange transfusions required. They manifested agglutination in Coombs serum at a 1:2048 titer and were strongly agglutinated by P.V.P with no subsequent dispersion of these agglutinates on resuspension in saline during 24 hours at room temperature. Their osmotic fragility was normal and their mechanical fragility was slightly increased (10 per cent). As with red cells sensitized with potent anti-D serum in vitro (Figure 6 ), most of these red cells were rapidly sequestered by the spleen. However, almost 30 per cent of the red cells escaped destruction, as indicated. The infant's mother had a 1:64 titer in 25 per cent albumin of incomplete anti-D antibody, and after birth the child developed anemia and jaundice within a few hours and exhibited hepatosplenomegaly. 
were sequestered within 10 minutes of injection. The pathologically sensitized red cells from a patient with a moderately severe acquired hemolytic anemia were simultaneously given to a normal subject and to the multiple myeloma patient (Figure 11). Here is shown the rapid sequestration of about $\mathbf{4 0}$ per cent of these red cells in the spleen of the normal subject, and the even more rapid and more complete sequestration by the impalpable spleen of the multiple myeloma patient.

The distribution subsequent to their injection into a dog of autogenous red cells sensitized in vitro to the Coombs test by their previous exposure to $\mathrm{CrCl}_{\mathbf{3}}$ is presented in Table $\mathrm{I}$. Two hours after their injection, 37.1 per cent of these cells had disappeared from the circulation, and of these over two-thirds were removed by the spleen.

\section{Destruction of sequestered red cells}

Although the injection of small volumes of red cells (i.e., containing about $1 \mathrm{Gm}$. of hemoglobin) into a subject with a circulating incomplete anti-

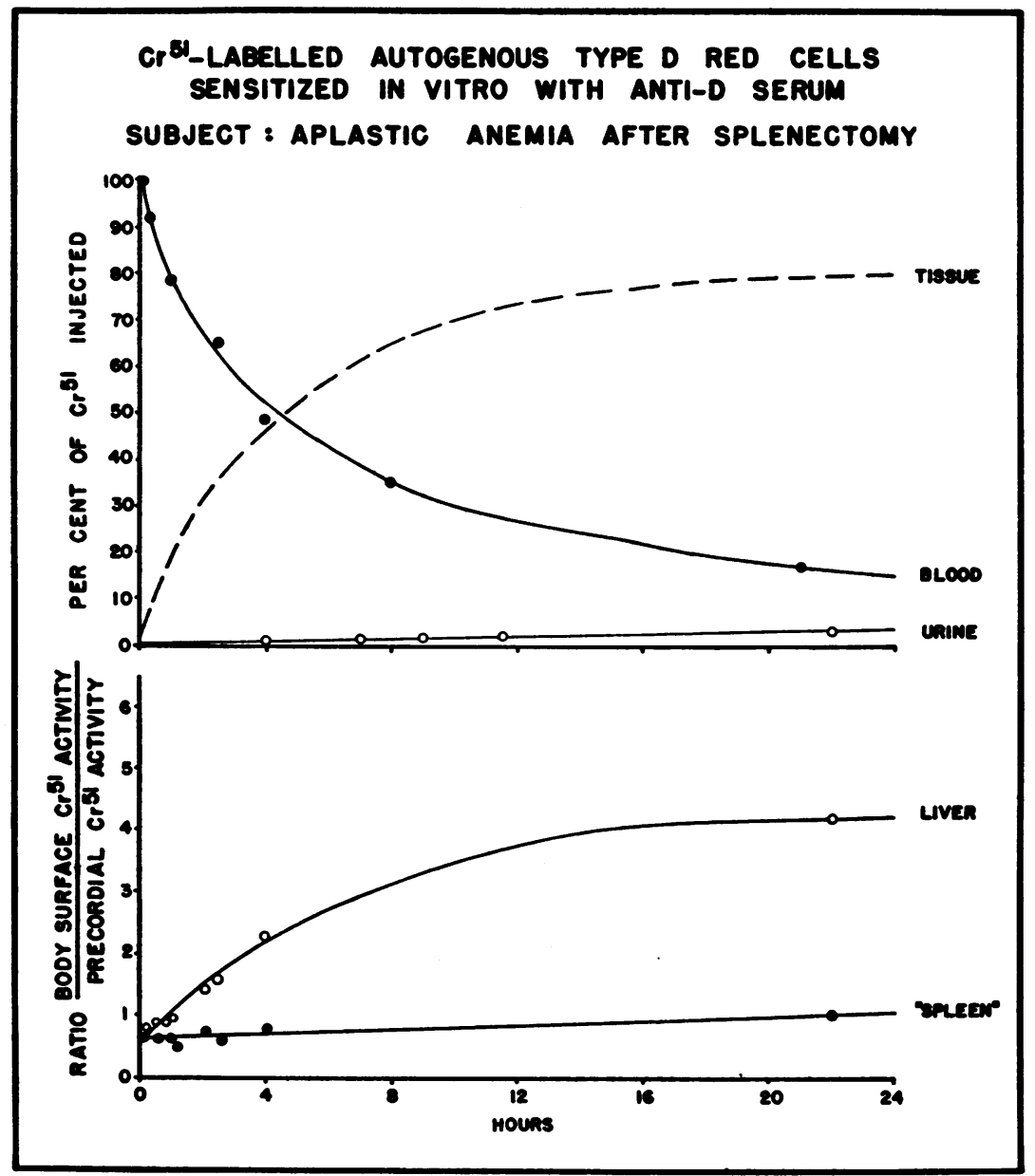

Fig. 10. Destruction in a Previously Splenectomized Subject of Autogenous Type D Red Cells Sensitized In Vitro With Anti-D Serum

Ten ml. of packed red cells from this adult subject with idiopathic aplastic anemia and a blood hemoglobin level of about $8 \mathrm{Gm}$. per cent were sensitized with the same incomplete anti-D serum that was used in the study depicted in Figure 6. In contrast to the half-survival of $\mathbf{3 0}$ minutes in that study, however, the halfsurvival of sensitized red cells in this splenectomized subject was prolonged to 4 hours and 40 minutes, and there was an appreciable accumulation of $\mathrm{Cr}^{\mathrm{m}}$ in the subject's liver. 


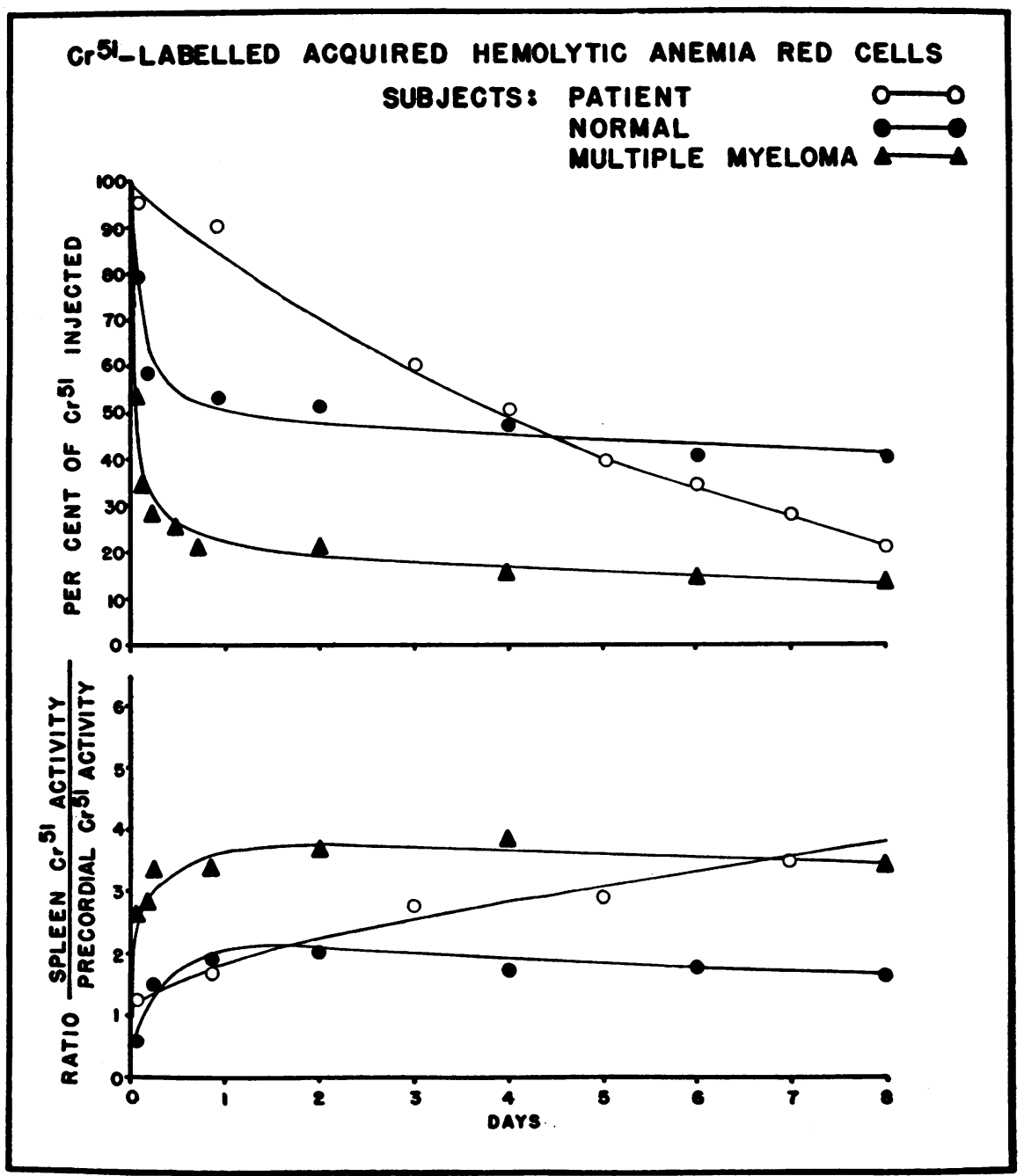

Fig. 11. Comparison of the Rate and Extent of Destruction of $\mathrm{C}^{61}$-Labelled Red Cells from a Patient With Acouired Hemolytic Anemia as Measured in Three Subjects: A Normal Subject, the Patient, and a Patient With Multiple MYeloma AND HyPERgLobulinemia

The rapid initial splenic sequestration of these cells in the normal subject resembles the patterns seen in other normal subjects given autogenous cells previously sensitized with certain anti-D sera (Figure 6), or red cells from an infant with erythroblastosis. The relatively slow rate of sequestration of the labelled red cells in the patient with acquired hemolytic anemia is believed to reflect the competition of the patient's circulating unlabelled cells for the splenic sequestering site. The red cells from the patient with acquired hemolytic anemia, as well as anti-D sensitized red cells (not shown), were sequestered even more rapidly and to a greater extent in the patient with multiple myeloma, whose hyperglobulinemic serum agglutinated the sensitized red cells in vitro. This patient's spleen was not palpable.

body, or the injection of similar volumes of previously sensitized red cells into normal subjects, was followed by little or no rise in plasma hemoglobin levels, the injection of larger volumes of cells produced detectable, albeit still low, levels of hemoglobin and of $\mathrm{Cr}^{51}$ in the plasma. In Figure 12 are depicted the individual levels of plasma hemoglobin and $\mathrm{Cr}^{51}$ following the injection of either type of red cell preparation containing $3.3 \pm$ $0.5 \mathrm{Gm}$. of hemoglobin. As revealed in this fig- 
ure plasma hemoglobin levels rose gradually after the red cell injections, reaching maximum values in $65 \pm 5$ minutes after injection of cells previously sensitized with anti-D serum into type D normal subjects and $53 \pm 12$ minutes after injection of $\mathrm{D}$-positive cells into hyperimmune recipients. Plasma $\mathrm{Cr}^{51}$ levels rose similarly, but declined more gradually.

The increases in plasma hemoglobin levels which follow injections of sensitized red cells were compared with those following intravenous infusion of hemoglobin solution into normal subjects at rates roughly one-half, and even one-tenth, the rate at which hemoglobin was theoretically released from the sequestered sensitized red cells (Figure 13). Accordingly, despite allowance for the rate of removal of hemoglobin from the plasma by the reticuloendothelial tissue, it appears that only a small fraction of the hemoglobin released from the sequestered red cells in these subjects escaped into the plasma.

The small increases in serum bilirubin levels
A
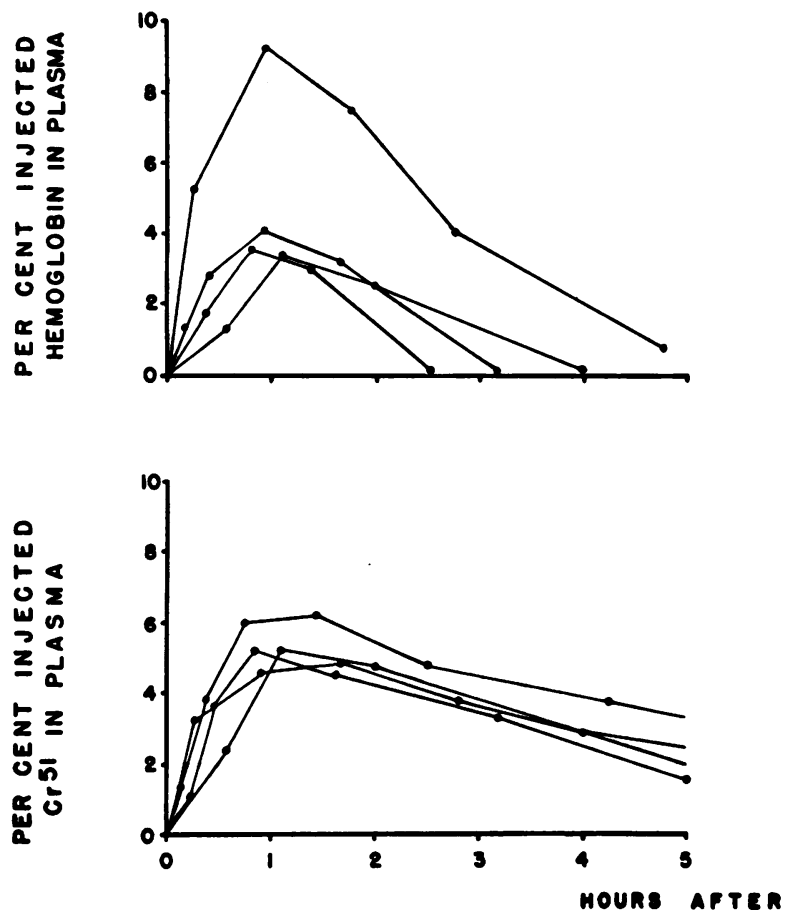

B
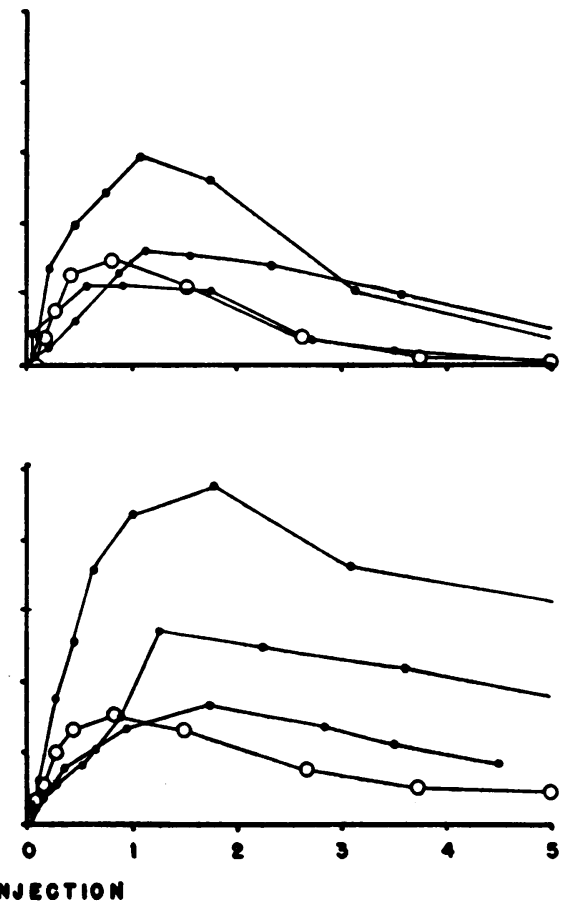

Fig. 12. Plasma Hemoglobin and $C_{R}{ }^{g 1}$ Levels Following the Injection of Anti-D Sensitized Red Ceils

The studies portrayed under "A" were carried out on four D-negative otherwise normal subjects whose serum contained incomplete anti-D antibodies. Calculated total circulating plasma hemoglobin values in these subjects rose to between 3.3 and 8.6 per cent of the injected hemoglobin slightly less than one hour after injection. Similarly, total plasma $\mathrm{Cr}^{\text {s1 }}$ values reached peak levels of from 4.6 to 6.1 per cent of the injected radioactivity about one hour after injection. The studies under " $B$ " were performed on four normal subjects who received red cells sensitized in vitro with potent incomplete anti-D antibodies. In the three type D subjects (solid circles) maximum values of from 2.1 to 5.8 per cent of the hemoglobin injected as sensitized autogenous cells appeared in the plasma a little more than an hour later; and the plasma $\mathrm{Cr}^{51}$ levels reached peak values of from 3.4 to 9.5 per cent of the injected dose about one and one-half hours after injection. The fourth subject (open circles), who was D-negative, showed similar findings but at a somewhat accelerated pace resembling that of the sensitized subjects under "A." The hemoglobin content of the injected cell suspensions ranged from 2.8 to $3.8 \mathrm{Gm}$. Thus, in both groups of subjects, only a small fraction of the injected hemoglobin appeared in the plasma. The regularly occurring gradual rises in plasma hemoglobin to maximum levels about one hour after the red cell injections suggest that the period of maximum hemolysis came within that hour. 


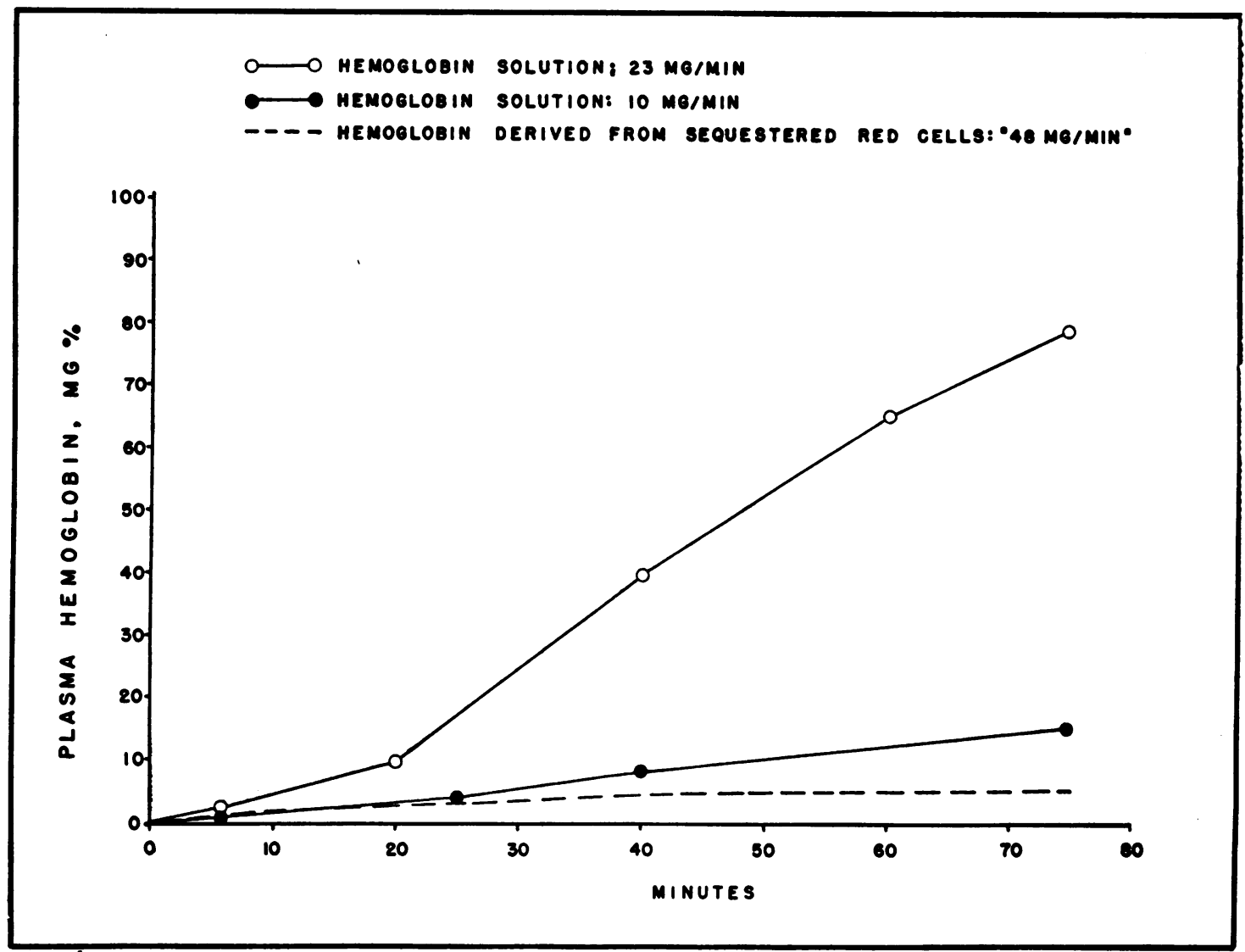

Fig. 13. Comparison of Plasma Hemoglobin Levels Following Infusions of Hemoglobin Solution and Injections of Anti-D Sensitized Red Cells

The dotted line represents the average plasma hemoglobin levels of seven normal subjects who received injections completed within two minutes of previously sensitized red cells containing an average of $3.1 \mathrm{Gm}$. of hemoglobin. Based on an average of the red cell survival studies, the quantity of hemoglobin released if these cells were immediately lysed was calculated to average about $60 \mathrm{mg}$. per minute during the first 26 minutes and about $36 \mathrm{mg}$. per minute during the next 34 minutes, with an overall average release of hemoglobin during the first hour of about $48 \mathrm{mg}$. per minute. Despite this potential rate of delivery of hemoglobin into the plasma, the maximum level reached at the end of one hour after injection of these cells averaged only about $5 \mathrm{mg}$. per cent above the base line. In contrast a steady infusion into a normal subject of hemoglobin solution at the rate of only $10 \mathrm{mg}$. per minute produced a plasma hemoglobin level at one hour of $12.5 \mathrm{mg}$. per cent; and the infusion of $23 \mathrm{mg}$. of hemoglobin per minute produced a plasma level of about $65 \mathrm{mg}$. per cent at one hour.

after the injection of anti-D sensitized red cells containing about $3 \mathrm{Gm}$. of hemoglobin into normal subjects were of doubtful significance. To observe better the change in serum bilirubin levels one normal subject was injected with a quantity of anti-D sensitized autogenous red cells containing $6.9 \mathrm{Gm}$. of hemoglobin. As revealed in the left portion of Figure 14, this led to a higher, more protracted rise in plasma hemoglobin levels than was seen after injection of smaller quantities of sensitized cells. An increase in the total serum bilirubin level first appeared about one hour after injection and rose to a maximum in about five hours, while a rise in the level of prompt directacting bilirubin was first evident between two and three hours, and also reached a maximum about five hours after injection. For comparison, hemoglobinemia of a similar magnitude was produced by the slow intravenous infusion of hemoglobin solution; this produced a comparatively small rise in serum bilirubin levels.

Further evidence of the speed of breakdown of sequestered red cells was sought by the use of $\mathrm{Fe}^{59_{-}}$ labelled reticulocytes. The rates of sequestration 
of $\mathrm{Fe}^{59}$-labelled reticulocytes sensitized in vitro with anti-D and injected into an ABO-compatible normal subject, into a patient with acquired hemolytic anemia from whom the reticulocytes were derived, and into another patient with acquired hemolytic anemia who had been splenectomized, are presented in Figure 15. These results conformed closely to previous observations on the same subjects employing $\mathrm{Cr}^{51}$-labelled mature sensitized red cells. Body surface radioactivity patterns were also similar to those produced with $\mathrm{Cr}^{51}$-labelled mature red cells, although stray radiations were more prominent with the higher energy gamma radiations of $\mathrm{Fe}^{58}$.

$\mathrm{Fe}^{50}$-labelled reticulocytes from a patient with acquired hemolytic anemia were hemolyzed with sterile distilled water after thorough washing of the cells, and the supernatant solution was adjusted to a sodium chloride concentration of 0.9 per cent, centrifuged relatively free of cell ghosts, and then passed through a Seitz filter prior to injection. Over 90 per cent of the $\mathrm{Fe}^{58}$ was in hemoglobin as determined with filter paper electrophoresis. Upon injection into two normal subjects, the hemoglobin

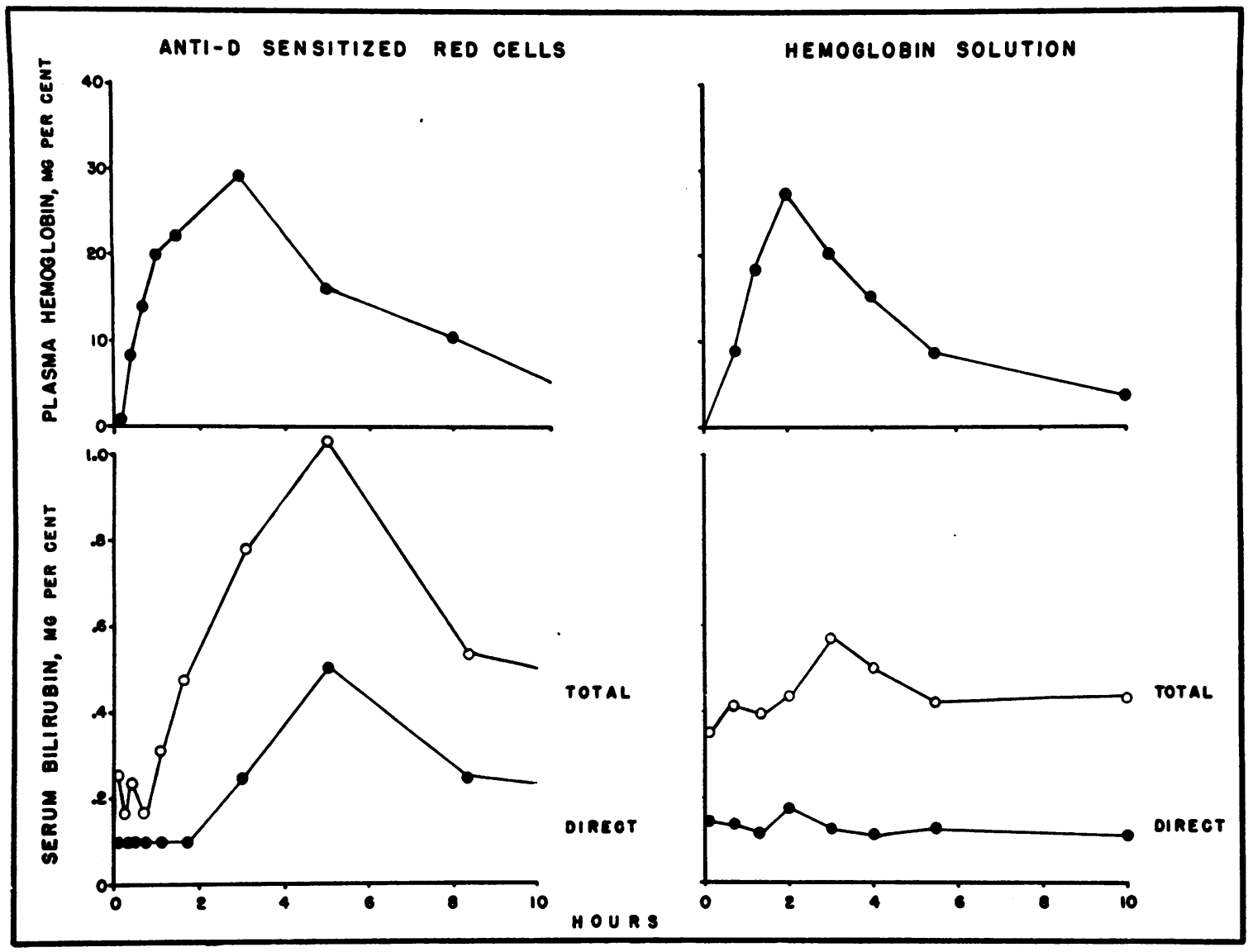

Fig. 14. Plasma Hemoglobin and Serum Bilirubin Levels in Normal Subjects Injected Either With Anti-D Sensitized Autogenous Red Cells or With Hemoglobin Solution

The injection of sensitized red cells (left above) containing $6.9 \mathrm{Gm}$. of hemoglobin led to an appreciably higher and more prolonged rise in plasma hemoglobin levels than was the case with smaller injections (Figures 4, 5, 6 and 11), although the rate of red cell sequestration was similar. Beginning an hour after the injection a rise in total serum bilirubin levels appeared, reaching a maximum in five hours. The initial rise consisted entirely of "indirect" reacting bilirubin; not until over two hours after injection did the prompt "direct" reacting bilirubin level rise. A similar degree of hemoglobinemia produced by slow infusion of hemoglobin solution (right above) caused only a relatively small and questionable increase in bilirubin levels. These data are interpreted to mean that most or all of the sequestered sensitized red cells were hemolyzed in situ and that this occurred within a short time of their sequestration. 


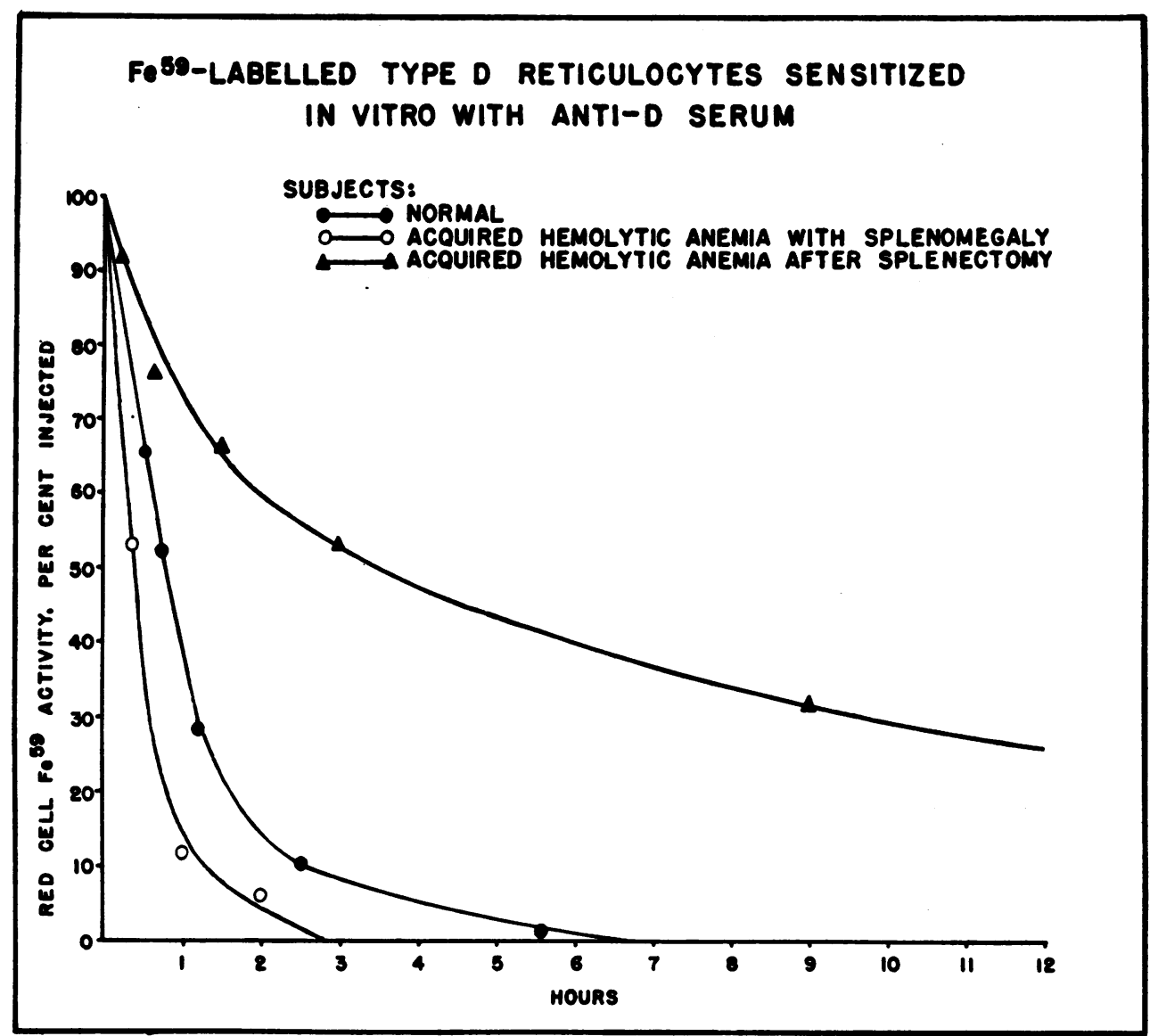

Fig. 15. Destruction of Fem-Labelled Reticulocytes Previously Sensitized In Vitro With Incomplete Anti-D Serum and Then Injected Into Three Different Recipients: A Normal Subject, a Patient With an Active Acquired Hemolytic Anemia and Splenomegaly, and a Patient Convalescing From an Acquired Hemolytic Anemia Several Months After Splenectomy

The rates of destruction of these sensitized cells closely resemble those determined in the same subjects with $\mathrm{Cr}^{52}$-labelled mature red cells. In the first two subjects prominent levels of $\mathrm{Fe}^{\mathrm{\omega}}$ activity appeared in the spleen, whereas in the splenectomized subject a comparatively high hepatic radioactivity developed (not shown) reciprocally with the fall in circulating red cell $\mathrm{Fe}^{\mathrm{m}}$ activity.

(benzidine) half-disappearance rates from the plasma were 2.2 and 2.4 hours and those of the $\mathrm{Fe}^{50}$ were 2.7 and 3.0 hours, respectively. A high relative hepatic radioactivity attended the removal of $\mathrm{Fe}^{59}$ from the blood. Radioactivity first appeared in these subjects' red cells about 18 hours after injection, and increased steadily thereafter while hepatic radioactivity gradually diminished (Figure 16).

The effect of the injection of anti-D sensitized, $\mathrm{Fe}^{30}$-labelled reticulocytes from a patient with acquired hemolytic anemia into a normal subject is shown in Figure 17. Here the $\mathrm{Fe}^{39}$ disappeared rapidly from the circulating red cells with a halfsurvival time of $\mathbf{4 0}$ minutes. As in the $\mathrm{Cr}^{51}$ studies, plasma hemoglobin levels reached a maximum about one hour after injection. The plasma $\mathrm{Fe}^{59}$ peak was not reached until two and one-half hours after injection. Concurrent with the red cell $\mathrm{Fe}^{59}$ disappearance, a high relative splenic radioactivity developed. Thereafter, red cell radioactivity remained low until from 30 to 36 hours after injection, when radioactivity began to accumulate progressively in the circulating red cells while splenic radioactivity steadily diminished. An almost identical time relationship occurred when this study 
was repeated in a second subject, using anti-D sensitized $\mathrm{Fe}^{59}$-labelled reticulocytes obtained from a patient with pernicious anemia during response to vitamin $B_{12}$ therapy. In a third subject reticulocytes from a pernicious anemia patient were agglutinated in vitro (" 1 to 2 plus") with a serum containing both a complete and an incomplete anti-C antibody prior to their injection into a normal subject. Again radioactivity began to appear in the circulating red cells between 30 and 36 hours after injection.

In order to observe the reutilization of injected
$\mathrm{Fe}^{59}$ in a recipient with rapid hemoglobin and iron turnover, $\mathrm{Fe}^{59}$-labelled reticulocytes from a patient with acquired hemolytic anemia with 35 per cent circulating reticulocytes and a low serum iron level were sensitized with anti-D serum and reinjected into the patient (Figure 18). Sequestration of these red cells by the patient's enlarged spleen occurred more rapidly than in the normal subjects, and a higher transient rise in plasma $\mathrm{Fe}^{59}$ appeared and reached a peak 1.5 hours after the injection. $\mathrm{Fe}^{59}$ is estimated to have first reappeared in the circulating red cells approximately six or eight

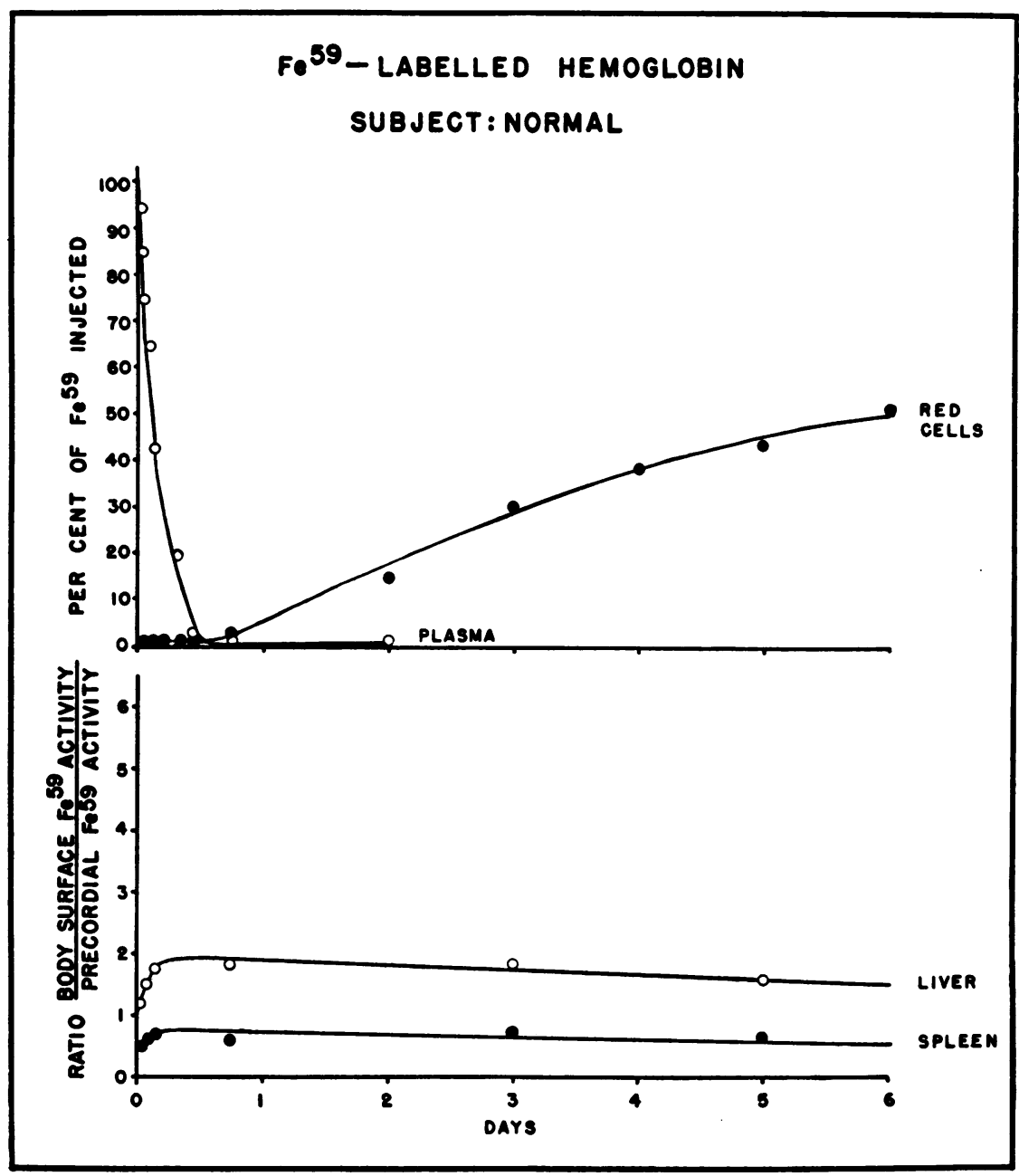

Fig. 16. Reutilization in a Normal Subject of Fe" Injected as Feso-Labelled HEMOGLOBIN

After injection of the radioactive hemoglobin solution, half of the $\mathrm{Fe}^{\infty}$ activity disappeared from the plasma within 2.6 hours, and all was gone in 12 hours. Meanwhile, radioactivity appeared and reached its maximum value in the subject's liver. Radioactivity was first detectable in small amounts in the subject's red cells 18 hours later, and within 10 days had accumulated to a total of 60 per cent of the injected dose. 


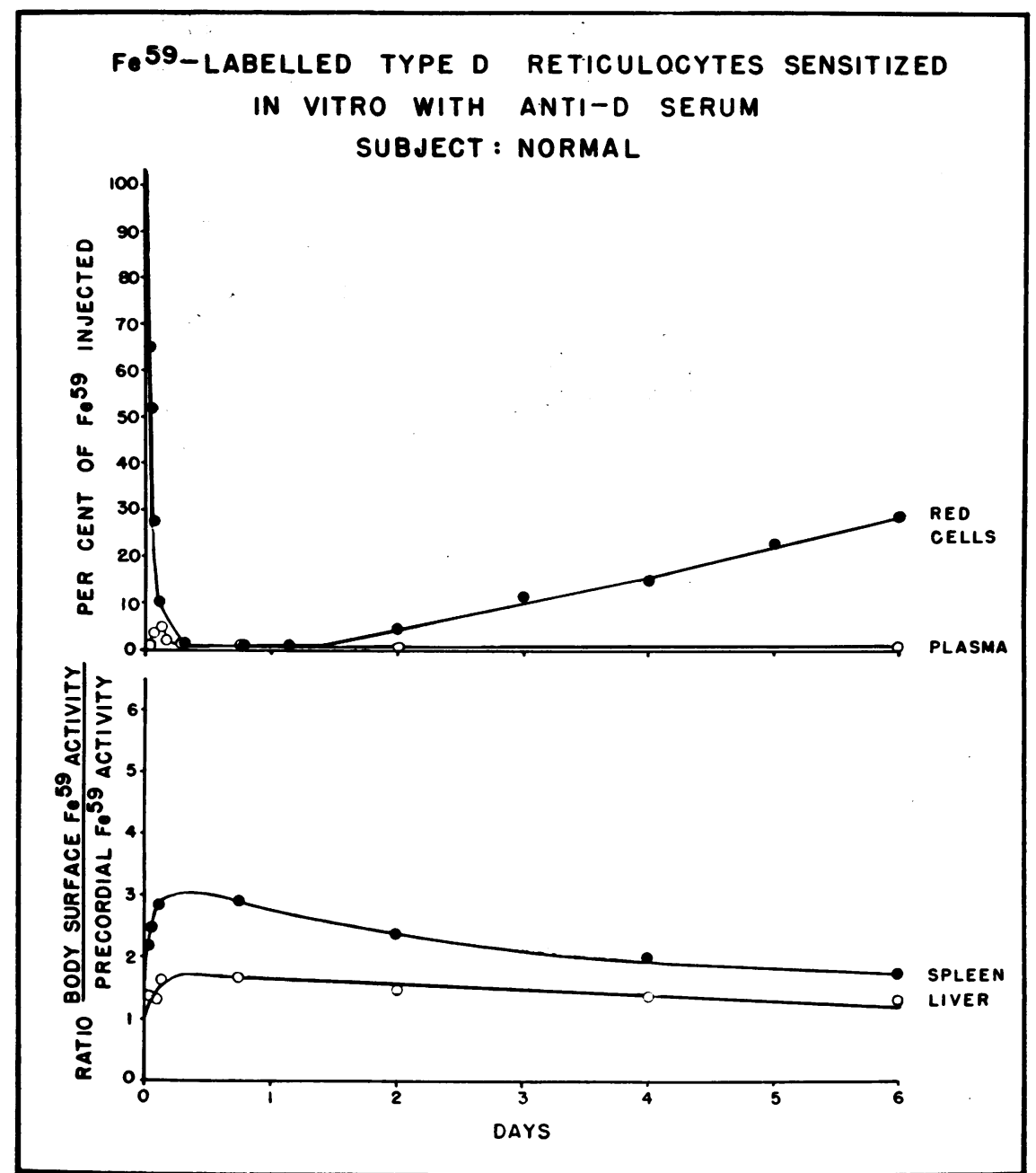

Fig. 17. Reutilization in a Normal Subject of Fe ${ }^{60}$ Injected as - Fe ${ }^{59}$-Labelled Anti-D Sensitized Reticulocytes

Although the rate of disappearance of $\mathrm{Fe}^{50}$ from the blood was more rapid (halfdisappearance time: 40 minutes) than following the injection of $\mathrm{Fe}^{50}$-labelled hemoglobin solution (Figure 13), reappearance of $\mathrm{Fe}^{\mathrm{so}}$ in the circulating red cells was first detected at 48 hours instead of at 18 and, as estimated by extrapolation, first appeared in the red cells 34 to 36 hours after injection. The prompt and relatively high splenic radioactivity declined more rapidly than after comparable experiments employing $\mathrm{Cr}^{51}$ labelled red cells.

hours after injection and increased rapidly to very high levels, along with a moderate fall in splenic radioactivity. A later gradual rise in radioactivity over the spleen presumably reflected sequestration of newly produced red cells as a manifestation of the disease process.

\section{DISCUSSION}

The injection into a normal subject of $\mathrm{Cr}^{51}$ labelled red cells previously sensitized with potent incomplete anti-D antibodies leads to the rapid almost total filtration of these cells by the normal spleen, as indicated by a striking rise in splenic radioactivity. Although not agglutinated by the sensitizing serum or by the recipient's plasma, half of these cells are sequestered within about $25 \mathrm{~min}$ utes. During this period smatl numbers of agglutinated red celfs are visible in the recipient's blood, but hemoglobin appears in the plasma only in relatively small amounts reaching a maximum level 60 
to 70 minutes after the injection. That the same sequence ensues after the injection of anti-D sensitized $\mathrm{D}$-positive red cells into $\mathrm{D}$-negative recipients, indicates that the normal mechanisms for filtering these cells do not require a specific immune interaction between cell "coating" and filter. Rather the spleen appears to act passively as a highly efficient filter.

That the quality and the quantity of antiserum used in the passive red cell sensitization experiments are critical to the manner in which the sensitized red cells are subsequently destroyed in vitro, is illustrated in Figures 7 and 8. Presumably such factors were iresponsible for the normal survival, after initial destruction of a small portion of the cells, of the remainder of the red cells sensitized in vitro by Mollison and Paterson (50). Loutit and Mollison (51) found that red cell agglutinates produced in vitro by anti-A serum appeared largely to disperse in the circulation of type A subjects, in that the survival of such pre-agglutinated red cells was relatively normal. The observations on the first of our subjects so studied, however, indicate that retention of the red cell agglutinates may oc-

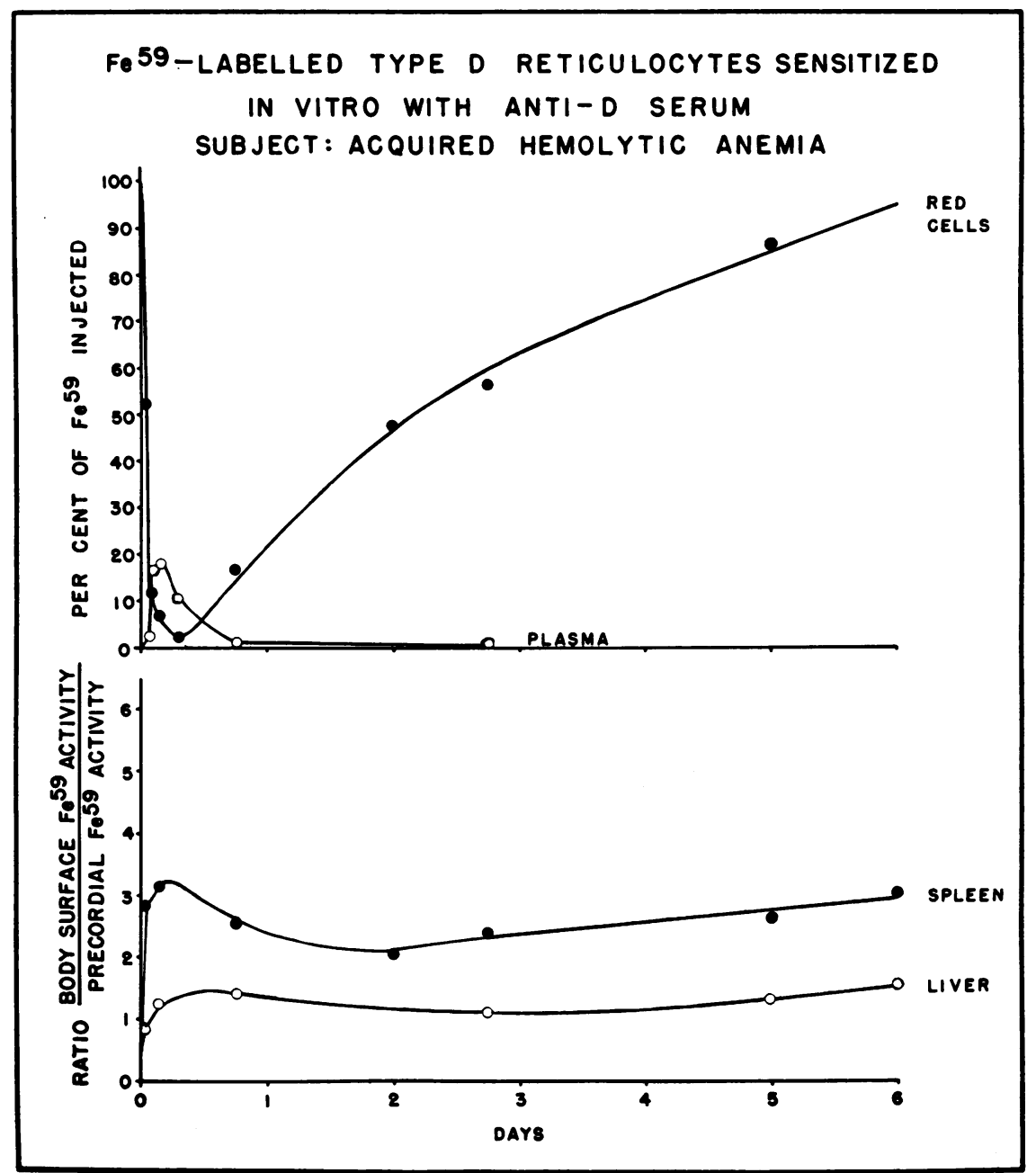

Fig. 18. Reutilization in a Subject With Acquired Hemolytic Anemia and Iron Deficiency of Fe ${ }^{50}$ Injected as Fe ${ }^{50}$-Labelled Anti-D Sensitized ReticuLOCYTES

In contrast to their fate in the normal subject (Figure 14) these reticulocytes were sequestered more rapidly, plasma $\mathrm{Fe}^{\mathrm{s0}}$ levels reached higher values, and $\mathrm{Fe}^{50}$ reappeared more quickly in the circulating red cells (within six or eight hours of injection) in association with a more rapidly-diminishing splenic radioactivity. 
cur before such dispersion has come about and that this retention occurs to a large extent in the liver. That this temporary sequestration may persist for an hour or so with only a fraction of the retained cells becoming hemolyzed is in contrast with the permanent sequestration and the apparent rapid hemolysis ensuing in the experiments involving anti-D and anti-C. It has been shown that when red cells are sensitized with various anti-D sera and are then agglutinated by substances which cause rouleaux, the permanence of these agglutinates when they are subsequently suspended in saline varies with the particular antiserum employed; these differences in the agglutinates of red cells sensitized with various incomplete anti-D sera are not due to simple elution of the antibodies but reflect qualitative differences in the "stickiness" induced by the antibodies (30). In the anti-D experiments described above, the degree of destruction of sensitized red cells in vivo correlated well with the persistence of P.V.P.-induced agglutinates of these cells in vitro.

Type D Cr ${ }^{51}$-labelled normal red cells, given to D-negative subjects with circulating incomplete anti-D antibodies, are removed somewhat more rapidly than in the experiments described above on normal D-positive subjects injected with D-sensitized red cells. Sequestration of the injected cells was less prominent in the spleens of sensitized subjects, and a considerable hepatic uptake of radioactive cells was also demonstrable, particularly when sequestration was most rapid. In these subjects, also, plasma levels of hemoglobin and of $\mathrm{Cr}^{51}$ rose slowly after injection to low maximum levels about 50 to 60 minutes after injection.

In D-negative subjects with both complete and incomplete anti-D or anti- $\mathrm{C}$ antibodies, red cell sequestration occurred even more rapidly, and hepatic sequestration was still more prominent, in some cases exceeding that of the spleen. The difference in body distribution of $\mathrm{Cr}^{51}$ in hyperimmunized subjects from that of normal subjects given previously-sensitized red cells might reflect simply a difference in the quantity of antibody. However, the fact that a comparatively large hepatic uptake may occur in hyperimmunized subjects even when the disappearance rate of injected red cells is similar to that of normal subjects receiving presensitized cells is more suggestive of qualitative rather than a quantitative dif- ference in the mechanisms of hemolysis. Thus, the more striking hepatic sequestration of type D cells in subjects with circulating incomplete anti-D antibody suggests that the filtering mechanism here may be specifically sensitized to the red cell antigen, in addition to operating simply as a passive filter. Visible evidence of such an interaction between type $\mathrm{D}$ red cells and the granulocytes of sensitized subjects has been noted recently by one of the authors (49). Indeed, clumping in vitro of the red cells of patients with acquired hemolytic anemia around the patients' leukocytes was observed as an early stage of erythrophagocytosis by Zinkham and Diamond (52). Swisher (53) has reported the appearance of mixed agglutinates of canine red cells, leukocytes and platelets when the red cells were exposed to canine anti-A. Further work along this line will be required to explain the difference in the pattern of sequestration of sensitized red cells by normal as compared to hyperimmune recipients.

The brisk and peculiar fashion in which the normal spleen filters sufficiently sensitized red cells from the circulation without intravascular hemolysis suggests that a physical or physicochemical mechanism involving the surfaces of the red cells is operative, rather than one involving metabolic changes within the red cells. The spleen's proficiency as a discriminating filter for spherocytes (54-57) and certain other particles (58) is well established and can be explained on purely mechanical grounds. Since the size, shape and viscosity of red cells are unaltered by sensitization with incomplete antibodies, an explanation must be sought in their tendency either to adhere to one another or to other cells. The belief that red cell agglutination is an intermediate step in the destruction of sensitized cells became tenable with the demonstration of a "conglutinating" action of normal plasma (28) and more recently by the finding that all rouleaux-producing substances, including fibrinogen and the other plasma globulins, categorically are active in this respect (30). Although the agglutination-enhancing effect of most of the tube tests employing serum as a diluent and of the slide test for incomplete antibodies (59) depends upon some degree of evaporation and the formation of surface layers of protein when normal serum is used, undehydrated plasma from normal persons often produces a slight partial ag- 


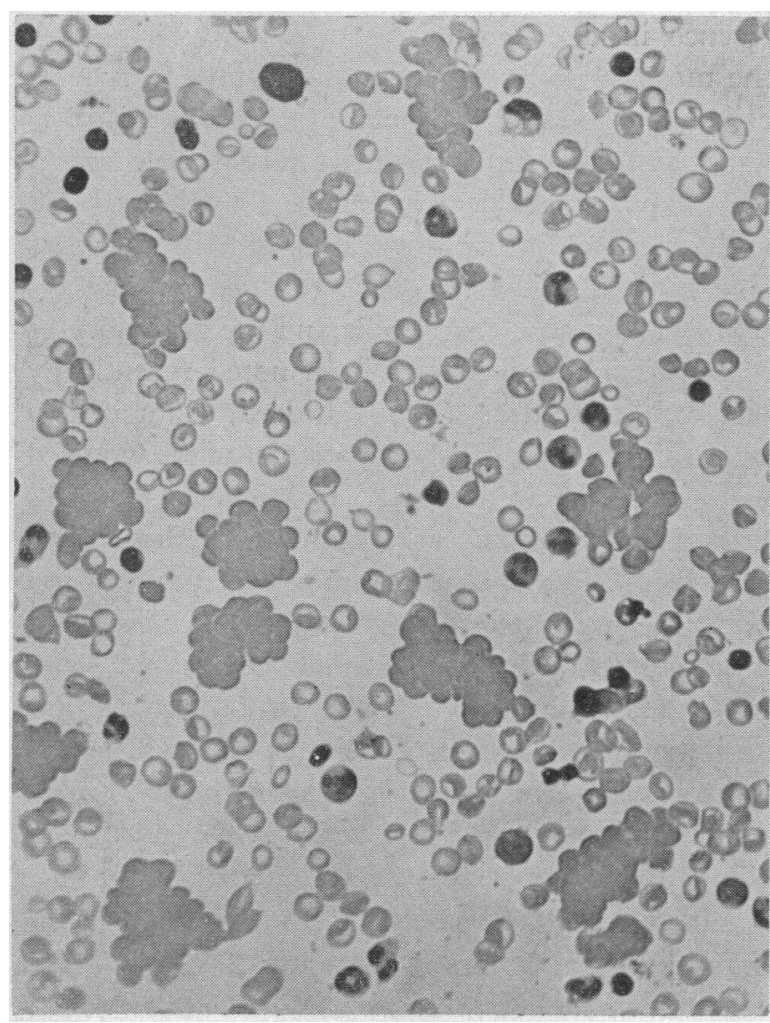

Fig. 19. Red Cell Agglutinates in the Splenic Pulp Blood of a Patient With Acquired Hemolytic Anemia and No Peripheral Autoagglutination

This smear was prepared from blood escaping from the freshly-incised surface of the patient's spleen shortly after its surgical excision. This blood revealed an icterus index of 50, a 2 to 3 plus Coombs test, a 4 plus P.V.P. test, and 2 plus agglutination in saline, while the peripheral blood drawn at the same time showed an icterus index of 12, a 2 plus Coombs test, a 4 plus P.V.P. test and no agglutination in saline. Incubation of the splenic pulp blood plasma with normal red cells produced evidence of red cell sensitization but not of agglutination. In spite of the impression that the agglutinated cells appear dense and spheroidal, the osmotic fragility of the splenic pulp red cells was only slightly greater than that of peripheral venous blood red cells ( 50 per cent hemolysis at $0.55 \mathrm{Gm}$. per cent $\mathrm{NaCl}$ compared to $0.51 \mathrm{Gm}$. per cent, respectively).

glutination of red cells sensitized with incomplete antibodies, and in persons with high sedimentation rates this effect may be pronounced $(30,60)$. The observations reported above on the accelerated sequestration of sensitized red cells injected into a subject with hyperglobulinemia support the contention that the concentrations in vivo of those substances which cause rouleaux in vitro (notably fibrinogen and other globulins) are critical to the sequestering mechanism.

In three cases of acquired hemolytic anemia not included in the studies reported above, comparisons were made between the survival patterns of the patients' $\mathrm{Cr}^{51}$-labelled red cells in the patients themselves and in normal subjects. The results closely resembled those depicted for the "patient" and the "normal" subject in Figure 11. Analogous observations have also been made by the authors upon the survival of red cells from a patient with hereditary spherocytosis in a normal subject and in the patient himself. Thus, small volumes of red cells from patients with hemolytic anemias were consistently destroyed with greater initial rapidity when injected into compatible normal subjects than when reinjected into the patients themselves. This probably reflects the smaller volume of abnormal red cells relative to the volume of filtering tissue in the normal recipient and thus indicates that the patients' red cells competitively occupy the filter receiving the labelled cells. Presumably it is on this basis that the destruction of small volumes of anti-D sensitized red cells described in this report proceeds so much more rapidly in normal subjects than in the corresponding clinical state of erythroblastosis fetalis. This preferential filtration of small volumes of anomalous red cells undoubtedly favors the detection of red cell incompatibility by trial transfusions of very small quantities of isotopelabelled red cells into patients suspected of being immunized to the red cells in question, as reported by Mollison and Cutbush (61).

On the other hand, if one assumes that the rate of filtration of abnormal red cells from the circulation in hemolytic anemias is limited by the available volume of sequestering tissue, then necessarily the disappearance rate of a given volume of patients' labelled abnormal red cells will be inversely proportional to the total volume (labelled and unlabelled) of abnormal red cells in the circulation. In this sense study of the survival of small volumes of labelled, pathological red cells reinjected into an afflicted patient is a tracer study of the turnover rate of the patient's entire red cell mass and can be analyzed accordingly; however, study of the survival of red cells taken from a patient with hemolytic anemia and injected into a normal subject is in no sense a tracer study and may provide mis- 
leading evidence for too rapid a rate of red cell turnover in the patient.

Direct evidence of the role of red cell agglutination in the destruction of sensitized cells was the fiinding that circulating agglutinates appeared in the peripheral blood of normal subjects receiving previously sensitized but unagglutinated red cells, providing the rate of removal was not so rapid as apparently to preclude such an observation. Blood obtained at operation from the freshly-incised spleen of a patient with acquired hemolytic anemia, a positive Coombs test in the absence of spontaneous autoagglutination, and a high splenic uptake of $\mathrm{Cr}^{51}$-labelled autogenous red cells, contained, in contrast to the peripheral blood, numerous red cell agglutinates (Figure 19). This finding further supports the intermediate role of agglutination, although conceivably the spleen may contain levels of an agglutinating antibody not apparent in the peripheral blood. Studies in this laboratory of the spleen blood of dogs anesthetized with Nembutal indicate that not only was there a marked concentration of red cells, as originally observed by Barcroft $(62,63)$, but that the plasma protein concentrations were also increased in the spleens of four of five dogs studied (Table II). Since splenic hematocrit levels in these dogs reached as high as 97 per cent, ${ }^{10}$ it is apparent that even the minor increases generally observed in the osmotic fragility (and thus in the water content) of "splenic" red cells would of necessity dehydrate the suspending plasma. Any increase in the concentration of plasma globulins (including fibrinogen) would, as stated above, induce or intensify red cell agglutination. However, whether or not the greater tendency of sensitized red cells to agglutinate in the blood stream of normal subjects than in their whole blood in vitro is an expression of local hyperproteinemia is not fully clarified.

Once sequestration of sensitized red cells in the spleen has occurred by virtue of their agglutinability, it appears that their actual destruction follows within a matter of minutes. This was apparent in several ways. Following the injection of

10 Although many relaxing and anesthetic agents profoundly affect the hemodynamics of dog and cat spleens, rendering it difficult to translate such extreme hemoconcentration into human physiology, indirect measurements indicate that hemoconcentration exists in patients with splenomegaly unexposed to such medications (64). sufficient volumes of D-positive red cells "coated" with incomplete anti-D serum into normal subjects, or of D-positive red cells into hyperimmunized D-negative subjects, plasma hemoglobin levels began to increase within a few minutes, and generally reached maximum levels approximately one hour later (Figure 12). The average halfmaximum plasma hemoglobin level followed the average red cell half-survival time by less than 10 minutes, and the rises in plasma hemoglobin levels were roughly indirectly proportional to the decline in red cell $\mathrm{Cr}^{51}$ activity. The patterns of the plasma $\mathrm{Cr}^{51}$ levels resembled those of the plasma hemoglobin values except for their slower decline, a difference that has been observed with injections of $\mathrm{Cr}^{51}$-labelled hemoglobin and that apparently derives from a gradual elution of $\mathrm{Cr}^{51}$ from hemoglobin in vivo (33). These observations on plasma hemoglobin and $\mathrm{Cr}^{51}$ levels are most consistent with the interpretation that a single hemolytic process exists and that only a small fraction of the released hemoglobin is returned to the circulation. The alternative explanation, that only a small fraction of the injected red cells is hemolyzed by one mechanism intravascularly while the majority of the cells are being sequestered (but not hemolyzed by another mechanism until later), is somewhat objectionable in that it requires the intravascular hemolytic processes affecting the lesser fraction of cells to be almost synchronous with the sequestering process affecting the greater fraction.

Further evidence that most or all of the sensitized red cells were hemolyzed soon after their

TABLE II

Comparison of the red cell and protein concentrations of the large vessel and splenic blood of five male dogs under Nembutal (1) anesthesia

\begin{tabular}{|c|c|c|c|c|c|c|}
\hline \multirow[b]{2}{*}{ Dog } & \multicolumn{2}{|c|}{ Hematocrit, vol. \% } & \multicolumn{4}{|c|}{ Plasma total protein, Gm. \% } \\
\hline & Aorta & Spleen & $\begin{array}{l}\text { Vena } \\
\text { cava }\end{array}$ & $\begin{array}{l}\text { Vena } \\
\text { porta }\end{array}$ & Aorta & Spleen* \\
\hline $\begin{array}{l}S-1 \\
S-2 \\
S-3 \\
S-4 \\
S-5\end{array}$ & $\begin{array}{l}46.0 \\
43.0 \\
46.0 \\
42.5 \\
53.6\end{array}$ & $\begin{array}{l}90.0 \\
83.0 \\
93.0 \\
80.2 \\
97.0\end{array}$ & $\begin{array}{l}5.47 \\
6.83 \\
6.50 \\
5.50 \\
5.53\end{array}$ & $\begin{array}{l}5.59 \\
7.54 \\
6.03 \\
6.00 \\
5.20\end{array}$ & $\begin{array}{l}4.79 \\
7.55 \\
6.47 \\
5.24 \\
5.70\end{array}$ & $\begin{array}{l}7.38 \\
6.21 \\
9.53 \\
7.06 \\
7.13\end{array}$ \\
\hline Average & 46.2 & 88.6 & 5.97 & 6.07 & 5.95 & 7.46 \\
\hline
\end{tabular}

* The plasma hemoglobin level of the spleen blood ranged from 0.12 to 0.65 (average, 0.31 ) $\mathrm{Gm}$. per cent. At all other sites sampled the plasma hemoglobin levels were $0.01 \mathrm{Gm}$. per cent or less. 
sequestration emerged from studies of a subject injected with a relatively large quantity of anti-D sensitized autogenous red cells (Figure 14). In this subject the serum level of indirect-reacting bilirubin began to rise within an hour of injection of the sensitized red cells, and this rise reflected the breakdown of a much larger amount of hemoglobin than had appeared in the plasma. A similar disparity between the effects of intravenous injection of hemoglobin solutions and of plasma containing high titers of incompatible isoagglutinins on the plasma hemoglobin and bilirubin levels in normal subjects was observed by Ebert and Emerson (25). These workers stressed the relatively greater increase in serum bilirubin levels following the action in vivo of incompatible isoagglutinins, and reported that maximum increases in bilirubin levels occurred between two and six hours of the incompatible plasma injection. The time sequence of the bilirubin rise following injection of sensitized red cells depicted in Figure 14 may be compared with that observed by Duesberg (65) following direct intravenous infusions of large amounts of hemoglobin solution. In his observations serum bilirubin levels began to increase within one hour and reached maximum values in three to four hours.

In discriminating between "intravascular" and "extravascular" hemolysis it is generally difficult to be certain whether the assumed criteria represent qualitative or quantitative differences. The data cited in Figure 13 stress a prominent qualitative difference between lysis of red cells in the general circulation and that in sequestering organs. Based on comparisons of these data and the assumption that the rise in plasma hemoglobin levels after the injection of sensitized red cells reflects a single lytic process affecting all the sequestered red cells, one may estimate that about 90 per cent of the derived hemoglobin is retained within the spleen and other sequestering sites and is largely catabolized in situ. This finding is consistent with our observations on a patient with acquired hemolytic anemia, in whom the bilirubin level of the splenic vein blood was almost five times as high as that of the peripheral blood, although the plasma hemoglobin level of the splenic vein blood was only slightly higher than that of the peripheral venous blood.

The fact that the $\mathrm{Fe}^{58}$ of sequestered reticulo- cytes reappeared in newly-formed red cells within as short a time as six or eight hours after its injection, indicates that hemolysis in the spleen, catabolism of the released heme, and incorporation of the released iron by immature red cells were all accomplished within this span of time. In addition, corroborating previous studies by Ross (66), these observations indicate that the iron of injected hemoglobin solutions is available for erythropoiesis at approximately the same rate as iron attached to the plasma iron-binding protein. Thus, the $\mathrm{Fe}^{\mathrm{so}}$ disappearance and reutilization curves of Figure 16 resemble closely the composite values for injected plasma-bound radioiron for normal subjects compiled by Finch, Wolff, Rath, and Fluharty (67). Figure 17 depicts the rapidity with which sequestered red cells may be lysed and their products reutilized. However, comparison of Figures 16 and 17 reveals that in normal subjects the iron released from red cells sequestered in the spleen may be delayed in its reutilization by as much as 16 or 18 hours longer than iron released by intravascular hemolysis. The $\mathrm{Fe}^{59}$ studies also indicate that the injurious effect of antibody sensitization on reticulocytes (the only $\mathrm{Fe}^{\mathrm{50}}$-labelled cells) is similar to that on mature red cells. Finally, it is of interest to note that the anti-D sensitized red cells $\left(\mathrm{Fe}^{\mathrm{s}}\right.$-labelled reticulocytes) were destroyed very rapidly in a patient with active, severe, acquired hemolytic anemia (Figure 18), whose pathologically sensitized red cells were destroyed with similar speed (at least initially) when transfused into other subjects (Figure 11). Although Figure 11 suggests that on reinjection the patient's pathologically sensitized $\mathrm{Cr}^{\mathrm{s1}}$-labelled red cells competed with unlabelled red cells in becoming sequestered, it appears that the patient's spleen retained an ample reserve capacity for destroying quickly the more severely sensitized (anti-D coated) red cells.

The observations cited above indicate that following their sequestration by the action of nonhemolytic antibodies, sensitized red cells are catabolized in approximately the following time sequence: 1 ) The cells are hemolyzed within a few minutes; 2) the released hemoglobin is converted to bilirubin (largely in situ) within one to two hours; 3 ) and the derived iron is available to the bone marrow for reutilization within six to eight hours. 
Since lysis takes place within a few minutes of sequestration, it is highly unlikely that it is brought about by the mechanisms of red cell swelling (68) or degeneration of the red cell membrane $(69,70)$ secondary to stasis and hemoconcentration per se, albeit such a sequence probably occurs in hereditary spherocytosis $(54-57,68)$. Even the theory that sequestered red cells provoke by vascular obstruction and ischemia the release of injurious substances from the tissues (14) seems inadequate to account for the rapidity of action noted here. The search for preformed lysins of physiologic significance in the spleen and other tissues (71-75) has proved a difficult one, not as yet productive of a clear answer. Studies in progress in this laboratory indicate that granulocytopenia and monocytopenia are associated with the lysis of red cells coated with incomplete antibodies and that the leukocytes of subjects hyperimmunized to the D antigen may adhere promptly to type $D$ red cells and later phagocytose some of these red cells (49). That the fixed macrophages of the reticuloendothelial system may react to sensitized red cells similarly or even more strikingly (17), and that lysis, with or without phagocytosis, of trapped sensitized red cells may supervene seems likely. The lining cells of liver sinusoids have been observed to phagocytose protein-coated carbon particles within a fraction of a second $(76,77)$; therefore, it seems not unreasonable to suppose that such phagocytes may engulf and possibly hemolyze trapped sensitized red cells within a few minutes.

The injection of $\mathrm{Cr}^{51}$-labelled normal red cells into normal subjects with circulating isoagglutinins, but without demonstrable isohemolysins, active against the $A$ or $B$ antigens of the injected cells, led to a more abrupt removal of the injected cells than was observed with sensitized cells; and there rapidly appeared moderate levels of hemoglobin and of $\mathrm{Cr}^{51}$ in the plasma (Figure 2). The correspondingly abrupt appearance of high hepatic radioactivity contrasted with the slower accumulation of $\mathrm{Cr}^{51}$ by the liver following injection of $\mathrm{Cr}^{51}$-labelled hemoglobin solution. In subjects with demonstrable isohemolysins in addition to isoagglutinins, injection of incompatible red cells produced similar changes, except for the even greater rapidity of red cell destruction, higher and more immediate peak levels of plasma hemoglobin and $\mathrm{Cr}^{51}$, and smaller and more gradual $\mathrm{Cr}^{51}$ up- takes by the subjects' livers. It is possible that in those recipients not manifesting hemolysins in their plasma this prompt hemoglobinemia arises from a direct local action of isohemolysins present in certain tissues. The findings cited above indicate also that those red cells not directly hemolyzed were sequestered, probably as agglutinates, and that this occurred largely in the liver. Similarly, as noted above, red cells agglutinated in vitro with anti-B serum and reinjected into the donor were observed to lodge in the donor's liver, albeit temporarily. Again, in a study not reported in detail here, the reinjection into a normal subject of $\mathrm{Cr}^{51}$-labelled red cells which had been moderately agglutinated in vitro with $\mathrm{CrCl}_{3}$ led to their abrupt, although temporary, sequestration by the subject's liver as indicated by body surface radioactivity. In a dog the reinjection of the animal's red cells more strongly agglutinated in vitro with $\mathrm{CrCl}_{3}$ led to sequestration by the lung, and to a lesser extent by the liver.

Together these observations involving moderate or strong agglutination indicate the relative lack of participation of the spleen in the sequestration process, perhaps because of the greater blood flow through other filters efficient against coarse red cell aggregates. The tendency of such cells to lodge in the lung and the liver presumably depends in part upon the size of the agglutinates, the greater blood flow of these organs and, in the case of the lung, its position proximal in the circulation to the site of injection. The filtration of strongly agglutinated red cells by proximate capillary beds seems logically compatible with the manifest inability of such cell aggregates to traverse the capillary beds of various tissues. Nevertheless, the evidence of a tendency of agglutinating antibodies to produce red cell sequestration specifically in the liver rather than in the lung is striking. Hepatic congestion with red cell agglutinates was histologically observed in intact animals by Pearce (22) ; and later the sequestering process was observed directly (14) during low pressure perfusions of the livers of dogs with dog blood mixed in vitro with weakly agglutinating concentrations of anti-dog red cell immune serum. Recently, McKay and co-workers (78) has demonstrated the appearance of multiple minute mesenteric "thrombi" and pseudomembranous enterocolitis following the intra-aortic injection of incompatible red cells into 
dogs in shock. This effect is possibly attributable to the phenomenon cited above of agglutinative obstruction in a low pressure perfusing system. Experimental hemolytic anemias in fowl, produced by cationic copper, a potent red cell agglutinating agent, are also associated with hepatic congestion with aggregates of red cells (79). Indeed, patients with acquired hemolytic anemia and frank autoagglutination may develop tender, enlarged livers, which may well be on this basis, for in one such patient, reported elsewhere (33), the liver was found to sequester actively $\mathrm{Cr}^{51}$-labelled autogenous red cells.

The anatomic features of the hepatic circulation which may especially adapt this organ for the sequestration of red cell agglutinates have been described by Knisely, Bloch, Warner, and Piovella $(76,77,80)$. By direct microscopic visualization of the living amphibian and mammalian liver, these authors have demonstrated that the liver, like the spleen, has sinusoidal structures permitting the trapping and hemoconcentration of blood. Bloch $(77,80)$ also observed the rapid appearance of red cell aggregates in the portal venules following intra-portal injection of anti-red cell serum, and shortly thereafter the retention and concentration of such aggregates in the liver sinusoids was evident. It is of interest that very little phagocytosis of these "passively" agglutinated red cells was observed and that, as in human subjects given red cells previously agglutinated with complete antibodies, many of the sequestered, agglutinated red cells appeared to return to the circulation within a few hours. It seems reasonable to ascribe to the liver a function as a filter most effective in trapping particles of somewhat larger size than those easily discriminated by the spleen. There is less clinical information to suggest pathological exaggerations of this filtering action of the liver on blood cells than is the case with the diseased spleen. However, a troublesome aspect of the natural course of acquired hemolytic anemia associated with red cell sensitization is the frequent tendency of hematologic relapses to occur several months after successful splenectomy. In studies of two such patients with acquired hemolytic anemia in relapse the authors have observed hepatomegaly and unusually high hepatic radioactivity after the injection of $\mathrm{Cr}^{51}$-labelled autogenous red cells. Thus, one may conceivably face a clinical phenomenon of "hyper-hepatism," which may only appear or become manifest after removal of the spleen. Similarly, in rare instances, patients with hereditary spherocytosis have been reported to undergo hematologic relapses within a few months after splenectomy and to develop enlarged, tender livers engorged with red cells $(81,82)$.

As in the studies of $\mathrm{ABO}$ isoantibodies above, it may be difficult to exclude the presence in vivo either of circulating hemolysins in subliminal concentrations or of high local concentrations of isohemolysins. That immune incompatibility may exist in vivo which is not demonstrable in vitro has been reported in dogs (17) and in man (83). A further observation to this effect, with additional features, is recorded in Figure 20. A patient with idiopathic acquired hypogammaglobulinemia had a serum gamma globulin concentration of only 20 to $30 \mathrm{mg}$. per cent. Although her blood was type A, prolonged incubation of large volumes of her fresh serum with type B red cells failed to cause hemolysis, agglutination, or sensitization of these cells. Nevertheless, $\mathbf{C r}^{51}$-labelled type B red cells were destroyed at an accelerated rate in her circulation, after a delay of two to three days, and this destruction was attended by pronounced splenic sequestration. The sigmoidal red cell survival curve produced resembles that seen in certain of the occult transfusion incompatibilities cited above $(17,83)$. The initial delay might be interpreted either as a delay required for the stimulation of antibody formation, or for the injected cells to absorb sufficient amounts of a scarce antibody to cause their agglutination or sensitization. To explore these alternative possibilities this hypogammaglobulinemic patient was then given several small weekly injections of type $B$ red cells and thereafter a survival study of $\mathrm{Cr}^{51}$-labelled type $B$ red cells was repeated. At this time these "incompatible" red cells survived almost normally, without abnormal splenic sequestration, a finding consistent with the second interpretation.

There is dispute as to whether the red cells of patients with acquired hemolytic anemia are coated with an "autoantibody" that has developed specifically against the red cells as antigen. Nevertheless, red cells sensitized with a specific antibody, with a drug-antibody complex (84), or even with a nonimmunologic metallo-protein complex (48), 
behave similarly in vitro and in vivo. Examples of acquired hemolytic anemias associated with each of the classic types of "immune" red cell alteration have been observed in which it is clear that specific antibodies had not developed against the unaltered red cell acting as antigen. There have been reports of hemolytic anemias in man caused by: a complement-requiring hemolysin associated with quinidine sensitivity (85); intravenous injection of a metallic cation $\left(\mathrm{Cu}^{++}\right)$which strongly agglutinates red cells (86); and red cell sensitization associated with sensitivity to fuadin (84). Thus it appears that the mode of destruction of the red cell does not fundamentally depend upon the specific mechanism of "immune" alteration but chiefly upon whether the cell has been sensitized to the action of complement, whether the cell is agglutinated by the "antibody," or whether it is only agglutinable in the presence of certain co-factors. Based on the studies described above a schema is presented in Figure 21, depicting the several pathways of red cell destruction by antibodies and by the various antibody-like agents encountered in idiopathic acquired hemolytic anemia.

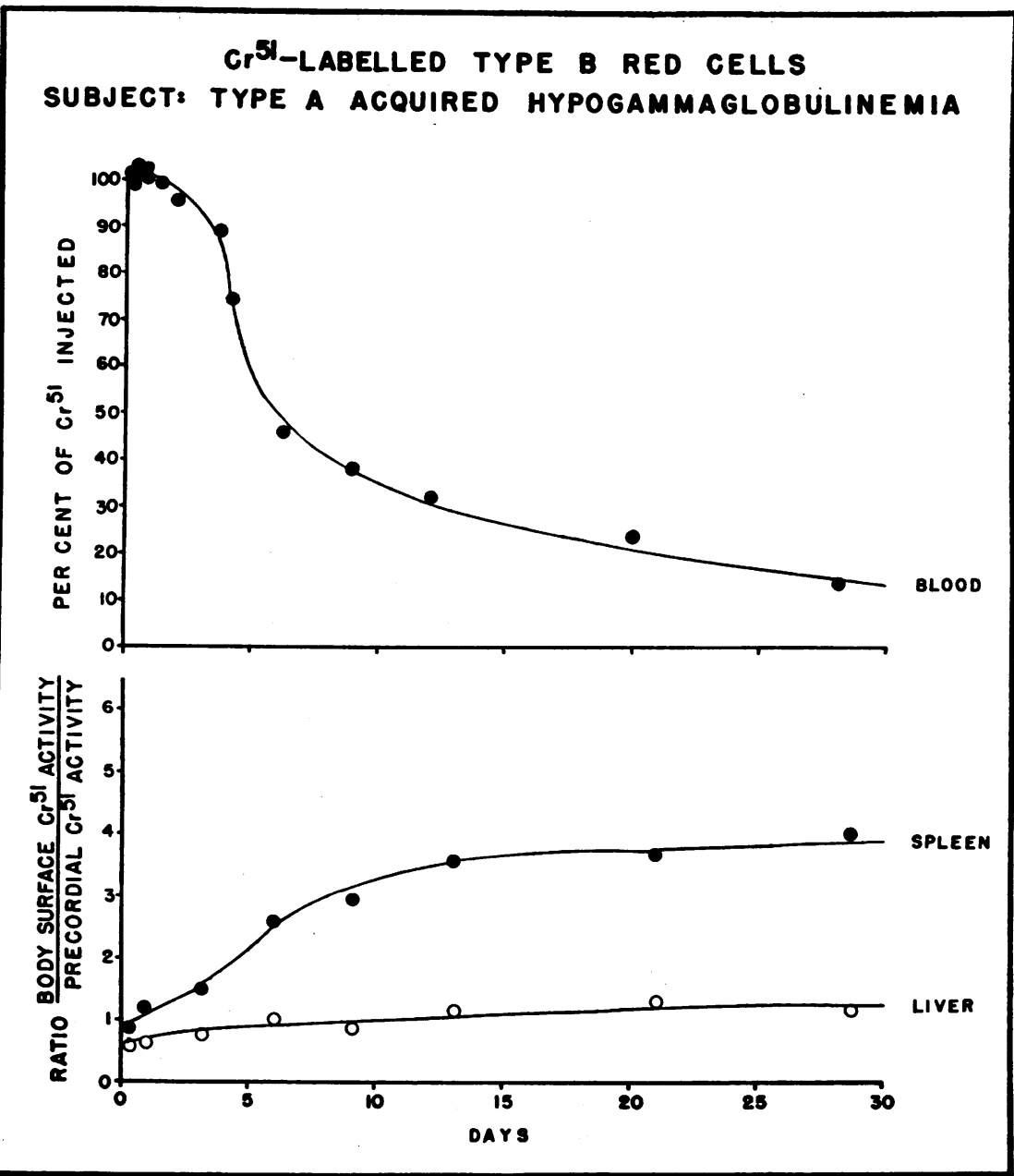

Fig. 20. The Destruction of Normal Type B Red Cells in a Type A PaTIENT With ACQUired Hypogammaglobulinemia aNd No IsOANTIbodies DemoNSTRABLE In Vitro

After a delay of almost two days, a rapid phase of circulating labelled red cell disappearance and of splenic red cell sequestration set in, with gradual slowing of both processes thereafter. Subsequent attempts to demonstrate anti-B antibody in vitro were again not fruitful. 


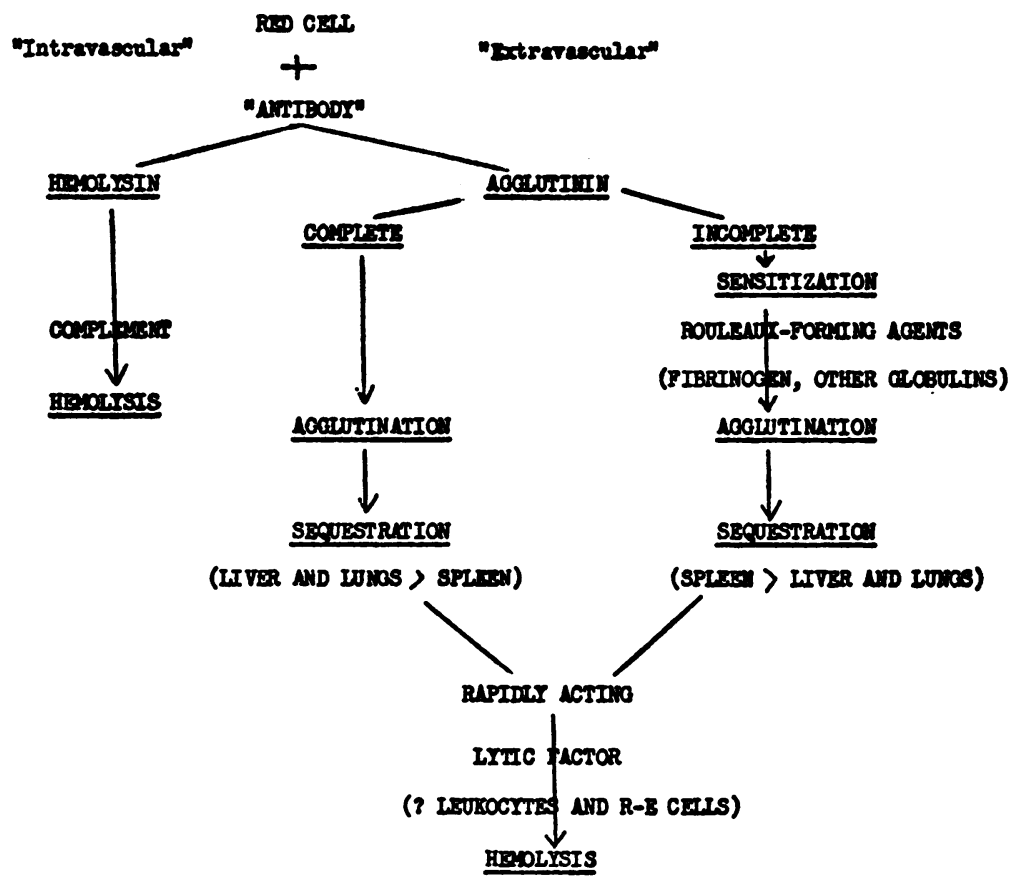

Fig. 21. Schema Depicting the Several Pathways of Red Cell DeStRUCtion by ANtibodies axd by the Various ANtibody-Like Agents EnCOUNTEREd in IdIOPATHic ACQUIREd Hemolytic ANEMia

\section{SUM MARY}

Studies were carried out in man on the mechanisms of destruction of red cells by antibodies, employing $\mathrm{Cr}^{51}$-labelled red cells and $\mathrm{Fe}^{50}$-labelled reticulocytes.

$\mathrm{Cr}^{51}$-labelled red cells sensitized in vitro with potent incomplete anti-D sera are rapidly and almost totally sequestered by the spleens of normal subjects. In sequestering sensitized red cells from the circulation, the spleen behaves as a highly proficient, passive filter. This sequestration is associated with slight increases of plasma hemoglobin reaching a maximum level 60 or 70 minutes after injection. Agglutination of injected sensitized red cells occurs in the circulation of normal subjects, probably as a consequence of the action of rouleaux-producing concentrations of plasma globulins, and represents an intermediate step in the mechanism of sequestration. These red cells are hemolyzed within a few minutes of their sequestration and hemoglobin breakdown occurs largely in situ. Reappearance in circulating red cells of the iron released from sensitized red cells begins after a delay of about 30 to 36 hours as compared to about 18 hours when the iron is derived from intravenously injected hemoglobin. The speed of red cell breakdown in the spleen necessitates the presence of a rapidly acting, probably preformed lysin. Work in progress indicates that leukocytes may be involved in this lytic process.

The injection of $\mathrm{Cr}^{51}$-labelled type $\mathrm{D}$ or $\mathrm{C}$ cells into normal subjects hyperimmunized against these cells leads to a similar, but slightly faster, pattern of events. Unlike the preceding observations, however, the liver sequesters a substantial proportion of the injected cells. It is probable that a specific interaction between the reticuloendothelial cells and the antigenic red cells exists in these subjects in addition to the passive filtering function of their otherwise normal spleens.

Intravenously injected $\mathrm{Cr}^{51}$-labelled $\mathrm{ABO}$-incompatible red cells are destroyed abruptly in subjects with isoagglutinins but no demonstrable isohemolysins. This is associated with prominent hepatic sequestration and moderate hemoglobinemia. In subjects with both agglutinins and demonstrable hemolysins red cell destruction is virtually instantaneous and presumably occurs in 
the general circulation, with prompt marked hemoglobinemia and slower, less pronounced hepatic accumulations of $\mathrm{Cr}^{51}$. It appears that virtually all normal persons possess some isohemolysins for $\mathrm{ABO}$-incompatible red cells, even when such hemolysins are not demonstrable in vitro by standard procedures. Generally, however, isoagglutination with hepatic sequestration is the chief mechanism of destruction of transfused ABOincompatible red cells. In man frank red cell agglutination produced in diverse ways was uniformly associated with a predominantly hepatic sequestration of the cells.

Studies of the analogous behavior of red cells from patients with acquired hemolytic anemia are presented and a schema is proposed to account for the pathways of destruction of the red cells of these patients.

\section{REFERENCES}

1. Bordet, J., Sur l'agglutination et la dissolution des globules rouges par le sérum d'animaux injectés de sang défibriné. Ann. de l'Inst. Pasteur, 1898, 12, 688.

2. Levaditi, C., Etat de la cytase hémolytique. Ann. de 1'Inst. Pasteur, 1902, 16, 233.

3. Kraus, R., and Sternberg, C., Ueber Wirkungen der Hämolysine im Organismus. Centralbl. f. Bakt., 1902, 32, 903.

4. Widal, F., Abrami, P., and Brulé, M., Auto-agglutination des hématies dans l'ictère hémolytique acquis. Compt. rend. Soc. de biol., 1908, 64, 655.

5. Chauffard, A., and Troisier, J., Contribution à l'étude des hémolysines dans leur rapport avec les anémies graves. Bull. et mém. Soc. méd. d. hôp. de Paris, 1908, 26, 94.

6. Muir, R., and M'Nee, J. W., The anaemia produced by a haemolytic serum. J. Path. \& Bact., 19111912, 16, 410.

7. Widal, F., Abrami, P., and Brulé, M., A propos du rôle hémolytique de la rate normale. Compt. rend. Soc. de biol., 1912, 72, 694.

8. Banti, G., Splénomégalie hémolytique anhémopoiétique; le rôle de la rate dans l'hémolyse. Semaine méd., 1913, 33, 313.

9. Dameshek, W., and Schwartz, S. O., Hemolysins as the cause of clinical and experimental hemolytic anemias. With particular reference to the nature of spherocytosis and increased fragility. Am. J. M. Sc., 1938, 196, 769.

10. Dameshek, W., and Schwartz, S. O., Acute hemolytic anemia (acquired hemolytic icterus, acute type). Medicine, 1940, 19, 231.

11. Bessis, M., Etudes sur lictère hémolytique expérimental par injection et ingestion d'antiserum. Rev. d'hémat., 1947, 2, 114.
12. Wasastjerna, $C_{\text {., }}$ On the influence of immune hemolysin on red blood corpuscles in vivo and vitro. Acta med. Scandinav., 1948, 132, 132.

13. Young, L. E., Ervin, D. M., and Yuile, C. L., Hemolytic reactions produced in dogs by transfusion of incompatible dog blood and plasma. Blood, 1949, 4, 1218.

14. Castle, W. B., Ham, T. H., and Shen, S. C., Observations on the mechanism of hemolytic transfusion reactions occurring without demonstrable hemolysins. Tr. A. Am. Physicians, 1950, 63, 161.

15. Wasastjerna, C., The destruction of red blood corpuscles in experimental hemolytic anemia. Acta med. Scandinav., 1951, Suppl. 258.

16. Samaille, J., and Jones, A. R., Protective mechanisms in experimental hemolytic anemia induced by hetero-immune sera. Fourth Congress, European Soc. Hematol., Amsterdam, 1953.

17. Swisher, S. N., and Young, L. E., Studies of the mechanisms of erythrocyte destruction initiated by antibodies. Tr. A. Am. Physicians, 1954, 67, 124.

18. Dacie, J. V., Hemolysins in acquired hemolytic anemia. Effect of $\mathrm{pH}$ on the activity in vitro of a serum hemolysin. Blood, 1949, 4, 928.

19. Dacie, J. V., The presence of cold haemolysins in sera containing cold haemagglutinins. J. Path. \& Bact., 1950, 62, 241.

20. Wiener, A. S., Blood Groups and Transfusion. Springfield, Illinois, Charles C Thomas, 1943.

21. Mollison, P. L., Blood Transfusion in Clinical Medicine. Oxford, Blackwell Scientific Publications, 1951.

22. Pearce, R. M., The experimental production of liver necroses by the intravenous injection of hemagglutinins. J. Med. Research, 1904, 12, 329.

23. Finland, M., and Curnen, E. C., Agglutinins for human erythrocytes in type XIV anti-pneumococcic horse serums. Science, 1938, 87, 417.

24. Tisdall, L. H., Garland, D. M., Szanto, P. B., Hand, A. M., and Bonnett, J. C., The effects of the transfusion of group $O$ blood of high iso-agglutinin titer into recipients of other blood groups. Am. J. Clin. Path., 1946, 16, 193.

25. Ebert, R. V., and Emerson, C. P., Jr., A clinical study of transfusion reactions: The hemolytic effect of group-O blood and pooled plasma containing incompatible isoagglutinins. J. Clin. Invest., 1946, $25,627$.

26. Ervin, D. M., and Young, L. E., Dangerous universal donors. I. Observations on destruction of recipient's A cells after transfusion of group $O$ blood containing high titer of $\mathrm{A}$ antibodies of immune type not easily neutralizable by soluble $A$ substance. Blood, 1950, 5, 61.

27. Day, R., and Perry, E., Intravascular hemagglutination. Experimental and clinical observations, with special reference to the pathogenesis of kernicterus. Blood, 1950, 5, 1114.

28. Wiener, A. S., Conglutination test for $\mathrm{Rh}$ sensitization. J. Lab. \& Clin. Med., 1945, 30, 662. 
29. Diamond, L. K., and Denton, R. L., Rh agglutination in various media with particular reference to the value of albumin. J. Lab. \& Clin. Med., 1945, 30, 821.

30. Jandl, J. H., and Castle, W. B., Agglutination of sensitized red cells by large anisometric molecules. J. Lab. \& Clin. Med., 1956, 47, 669.

31. Gray, S. J., and Sterling, K., The tagging of red cells and plasma proteins with radioactive chromium. J. Clin. Invest., 1950, 29, 1604.

32. Ebaugh, F. G., Jr., Emerson, C. P., and Ross, J. F., The use of radioactive chromium 51 as an erythrocyte tagging agent for the determination of red cell survival in vivo. J. Clin. Invest., 1953, 32, 1260.

33. Jandl, J. H., Greenberg, M. S., Yonemoto, R. H., and Castle, W. B., Clinical determination of the sites of red cell sequestration in hemolytic anemias. $\mathrm{J}$. Clin. Invest., 1956, 35, 842.

34. Jandl, J. H., Sequestration by the spleen of red cells sensitized with incomplete antibody and with metallo-protein complexes (abstract). J. Clin. Invest., $1955,34,912$.

35. Jandl, J. H., The rapid destruction of sequestered red cells as determined with $\mathrm{Fe}^{\mathrm{m}}$-labelled human reticulocytes. Clin. Research Proc., 1956, 4, 81.

36. Jandl, J. H., Observations on the pathway of destruction of red cells sensitized with incomplete antibodies. Proc. Sixth Congress of the Internat. Soc. of Hematology, August, 1956.

37. Walsh, R. J., Thomas, E. D., Chow, S. K., Fluharty, R. G., and Finch, C. A., Iron metabolism. Heme synthesis in vitro by immature erythrocytes. Science, 1949, 110, 396.

38. Report of the Sub-Committee on Human Applications of the Harvard Medical School Committee on Medical Research in Biophysics, May 7, 1949.

39. Ham, T. H., A Syllabus of Laboratory Examinations in Clinical Diagnosis. Cambridge, Mass., Harvard University Press, 1950.

40. Coombs, R. R. A., Mourant, A. E., and Race, R. R., $A$ new test for the detection of weak and "incomplete" Rh-agglutinins. Brit. J. Exper. Path., 1945, 26, 255.

41. Emerson, C. P., Franklin, W., and Lowell, F. C., The production of potent antihuman globulin (Coombs reagent) in rabbits immunized with serum adjuvant mixtures. J. Immunol., 1951, 66, 323.

42. Shen, S. C., and Ham, T. H., Studies on the destruction of red blood cells. III. Mechanism and complications of hemoglobinuria in patients with thermal burns: Spherocytosis and increased osmotic fragility of red blood cells. New England J. Med. 1943, 229, 701.

43. Shen, S. C., Castle, W. B., and Fleming, E. M., Experimental and clinical observations on increased mechanical fragility of erythrocytes. Science, 1944, $100,387$.

44. Keys, A., A rapid micro-Kjeldahl method. J. Biol. Chem., 1940, 132, 181.
45. Rutstein, D. D., Ingenito, E. F., and Reynolds, W. E., The determination of albumin in human blood plasma and serum. A method based on the interaction of albumin with an anionic dye-2-(4'-hydroxybenzeneazo) benzoic acid. J. Clin. Invest., 1954, 33, 211.

46. Malloy, H. T., and Evelyn, K. A., The determination of bilirubin with the photoelectric colorimeter. J. Biol. Chem., 1937, 119, 481.

47. Zieve, L., Hill, E., Hanson, M., Falcone, A. B., and Watson, C. J., Normal and abnormal variations and clinical significance of the one-minute and total serum bilirubin determinations. J. Lab. \& Clin. Med., 1951, 38, 446.

48. Jandl, J. H., and Simmons, R. L., The agglutination and sensitization of red cells by metallic cations: Interactions between multivalent metals and the red-cell membrane. Brit. J. Haemat., 1957, 3, 19.

49. Jandl, J. H., Pyrogenic and leukopenic effects of immune hemolysis in man (abstract). J. Clin. Invest., 1957, 36, 904.

50. Mollison, P. L., and Paterson, J. C. S., Survival after transfusion of $\mathrm{Rh}$-positive erythrocytes previously incubated with $\mathrm{Rh}$ antibody. J. Clin. Path., 1949, 2, 109.

51. Loutit, J. F., and Mollison, P. L., Haemolytic icterus (acholuric jaundice) congenital and acquired. $\mathrm{J}$. Path. \& Bact., 1946, 58, 711.

52. Zinkham, W. H., and Diamond, L. K., In vitro erythrophagocytosis in acquired hemolytic anemia. Blood, 1952, 7, 592.

53. Swisher, S. N., Nonspecific adherence of platelets and leukocytes to antibody-sensitized red cells: A mechanism producing thrombocytopenia and leukopenia during incompatible transfusions (abstract). J. Clin. Invest., 1956, 35, 738.

54. Emerson, C. P., Jr., Shen, S. C., and Castle, W. B., The osmotic fragility of the red cells of the peripheral and splenic blood in patients with congenital hemolytic jaundice transfused with normal red cells (abstract). J. Clin. Invest., 1946, 25, 922.

55. Emerson, C. P., Jr., Shen, S. C., Ham, T. H., and Castle, W. B., The mechanism of blood destruction in congenital hemolytic jaundice (abstract). J. Clin. Invest., 1947, 26, 1180.

56. Young, L. E., Platzer, R. F., Ervin, D. M., and Izzo, M. J., Hereditary spherocytosis. II. Observations on the role of the spleen. Blood, 1951, 6, 1099.

57. Weisman, R., Jr., Hurley, T. H., Harris, J. W., and Ham, T. H., Studies of the function of the spleen in the hemolysis of red cells in hereditary spherocytosis and sickle cell disorders. J. Lab. \& Clin. Med., 1953, 42, 965.

58. Björkman, S. E., The splenic circulation. With special reference to the function of the spleen sinus wall. Acta med. Scandinav., 1947, Suppl. 191.

59. Diamond, L. K., and Abelson, N. M., The demonstration of anti-Rh agglutinins-an accurate and rapid slide test. J. Lab. \& Clin. Med., 1945, 30, 204. 
60. Gorer, P. A., and Mikulska, Z. B., The antibody response to tumor inoculation. Improved methods of antibody detection. Cancer Research, 1954, 14, 651.

61. Mollison, P. L., and Cutbush, M., Use of isotopelabelled red cells to demonstrate incompatibility in vivo. Lancet, 1955, 268, 1290.

62. Barcroft, J., Some recent work on the functions of the spleen. Lancet, 1926, 210, 544.

63. Barcroft, J., and Poole, L. T., The blood in the spleen pulp. J. Physiol., 1927, 64, 23.

64. Rothschild, M. A., Bauman, A., Yalow, R. S., and Berman, S. A., Effect of splenomegaly on blood volume. J. Applied Physiol., 1954, 6, 701.

65. Duesberg, R., tber die biologischen Beziehungen des Hämoglobins zu Bilirubin und Hämatin bei normalen und pathologischen Zuständen des Menschen. Arch. f. exper. Path. u. Pharmakol., 1934, 174, 305.

66. Ross, J. F., The metabolism of inorganic and hemoglobin iron (abstract). J. Clin. Invest., 1946, 25, 933.

67. Finch, C. A., Wolff, J. A., Rath, C. E., and Fluharty, R. G., Iron metabolism. Erythrocyte iron turnover. J. Lab. \& Clin. Med., 1949, 34, 1480.

68. Ham, T. H., and Castle, W. B., Studies on the destruction of red blood cells. Relation of increased hypotonic fragility and of erythrostasis to the mechanism of hemolysis in certain anemias. Proc. Am. Philosoph. Soc., 1940, 82, 411.

69. Selwyn, J. G., and Dacie, J. V., Autohemolysis and other changes resulting from the incubation in vitro of red cells from patients with congenital hemolytic anemia. Blood, 1954, 9, 414.

70. Young, L. E., Izzo, M. J., Altman, K. I., and Swisher, S. N., Studies on spontaneous in vitro autohemolysis in hemolytic disorders. Blood, 1956, 11, 977.

71. Bergenhem, B., and Fåhraeus, R., Uber spontane Hämolysinbildung im Blut, unter besonderer Berücksichtigung der Physiologie der Milz. Ztschr. f. d. ges. exper. Med., 1936, 97, 555.

72. Maegraith, B. G., Findlay, G. M., and Martin, N. H., Lytic agent and inhibitory factors in human tissue and sera, changes in serum inhibitor factor in blackwater fever. Lancet, 1943, 244, 573.

73. Brückmann, G., and Wertheimer, E., Lysis of red blood cells by tissue slices. Brit. J. Exper. Path., 1945, 26, 217.
74. Tyler, D. B., An autohemolytic agent in fetal liver extracts. Proc. Soc. Exper. Biol. \& Med., 1949, 72, 491.

75. Magalini, S. I., Blumenthal, W., and Stefanini, M., A splenic hemolytic system of lipidic nature in man. Clin. Research Proc., 1956, 4, 81.

76. Knisely, M. H., Bloch, E. H., and Warner, L., Selective phagocytosis. I. Microscopic observations concerning the regulation of the blood flow through the liver and other organs and the mechanism and rate of phagocytic removal of particles from the blood. Det Kongelige Danske Videnskabernes Selskab. Biologiske Skrifter, 1948, 4, Nr. 7.

77. Bloch, E. H., The in vivo microscopic vascular anatomy and physiology of the liver as determined with the quartz rod method of transillumination. Angiology, 1955, 6, 340 .

78. McKay, D. G., Hardaway, R. M., III, Wahle, G. H., Jr., and Hall, R. M., Experimental pseudomembranous enterocolitis. Arch. Int. Med., 1955, 95, 779.

79. Goldberg, A., Williams, C. B., Jones, R. S., Yanagita, M., Cartwright, G. E., and Wintrobe, M. M., Studies on copper metabolism. XXII. Hemolytic ane$\mathrm{mia}$ in chickens induced by the administration of copper. J. Lab. \& Clin. Med., 1956, 48, 442.

80. Bloch, E. H., and Piovella, C., Microscopic observations of the acute effects on the extra- and intrahepatic circulation produced by anti-red cell sera. Anat. Record, 1955, 121, 459.

81. Freund, M., Hemolytic jaundice not influenced by splenectomy. Am. J. Dis. Child., 1932, 43, 645.

82. Gripwall, E., Zur Klinik und Pathologie des Hereditären Hämolytischen Ikterus. Acta med. Scandinav., 1938, Suppl. 96.

83. Jandl, J. H., and Greenberg, M. S., The selective destruction of transfused "compatible" normal red cells in two patients with splenomegaly. J. Lab. \& Clin. Med., 1957, 49, 233.

84. Harris, J. W., Studies on the mechanism of a druginduced hemolytic anemia. J. Lab. \& Clin. Med., 1954, 44, 809.

85. Freedman, A. L., Barr, P. S., and Brody, E. A., Hemolytic anemia due to quinidine: Observations on its mechanism. Am. J. Med., 1956, 20, 806.

86. Laroche, C., and de Gennes, J. L., Intoxication aiguë avec hémolyse par le sulfate de cuivre: Exsanguinotransfusions. Guérison. Bull. et mém. Soc. d. méd. hôp. de Paris, 1955, 71, 133. 